\title{
The westernmost Late Miocene-Pliocene volcanic activity in the Vardar zone (North Macedonia)
}

\author{
Kata Molnár ${ }^{1}$ (1) $\cdot$ Pierre Lahitte ${ }^{2} \cdot$ Stéphane Dibacto $^{2,3} \cdot$ Zsolt Benkó $^{1} \cdot$ Samuele Agostini ${ }^{4} \cdot$ Boglárka Dönczö $^{5}$. \\ Artur lonescu $^{6,7} \cdot$ Ivica Milevski $^{8} \cdot$ Zita Szikszai $^{5} \cdot$ Zsófia Kertész $^{5} \cdot$ Marjan Temovski ${ }^{1}$
}

Received: 2 April 2021 / Accepted: 7 December 2021 / Published online: 24 December 2021

(c) The Author(s) 2021

\begin{abstract}
Late Miocene to Pleistocene volcanism within the Vardar zone (North Macedonia) covers a large area, has a wide range in composition, and is largely connected to the tectonic evolution of the South Balkan extensional system, the northern part of the Aegean extensional regime. The onset of the scattered potassic to ultrapotassic volcanism south from the ScutariPeć transverse zone occurred at ca. 8.0 Ma based on this study. Here, we focused on three volcanic centers located on deep structures or thrust faults along the western part of the Vardar zone, for which there is none to very little geochronological and geochemical data available. Pakoševo and Debrište localities are represented as small remnants of lava flows cropping out at the southern edge of Skopje basin and at the western edge of Tikveš basin, respectively. Šumovit Greben center is considered as part of the Kožuf-Voras volcanic system, and it is located on its westernmost side, at the southern edge of Mariovo basin, which is largely composed of volcaniclastic sediments. We present new eruption ages applying the unspiked Cassignol-Gillot $\mathrm{K}-\mathrm{Ar}$ technique on groundmass, as well as petrological and geochemical data, supplemented with $\mathrm{Sr}$ and $\mathrm{Nd}$ isotopes to complement and better understand the Neogene-Pleistocene volcanism in the region. Eruption ages on these rocks interlayered between sedimentary formations allow to better constrain the evolution of those sedimentary basins. Rocks from the three volcanic centers belong to the high-K calc-alkaline-shoshonitic series based on their elevated K content. The oldest center amongst these three localities, as well as other Late Miocene centers within the region, is the trachyandesitic Debrište, which formed at ca. 8.0 Ma, and exhibits the highest $\mathrm{Nd}$ and lowest $\mathrm{Sr}$ isotopic ratios (0.512441-0.512535 and 0.706759-0.706753, respectively). The basaltic trachyandesite Pakoševo center formed at ca. 3.8 Ma and its Nd and $\mathrm{Sr}$ isotopic ratios ( 0.512260 and 0.709593 , respectively) bear the strongest signature of crustal contamination. The rhyolitic Šumovit Greben center is a composite volcanic structure formed at ca. 3.0-2.7 Ma. Its youngest eruption unit has a slightly higher $\mathrm{Nd}$ and lower $\mathrm{Sr}$ isotopic ratios (0.512382 and 0.709208 , respectively) representing a magma with a lesser extent of crustal assimilation than the other samples from this center. The overall trend through time in the $\mathrm{Sr}$ and $\mathrm{Nd}$ isotopic ratios of the Late Miocene to Pleistocene mafic volcanic centers in the region implies an increasing rate of metasomatism of the lithospheric mantle.
\end{abstract}

Keywords Unspiked Cassignol-Gillot K-Ar dating $\cdot$ Late Miocene-Pleistocene $\cdot$ Volcanism $\cdot$ Vardar zone $\cdot \mathrm{Sr}$ and $\mathrm{Nd}$ isotopes

Kata Molnár

molnar.kata@atomki.hu

1 Isotope Climatology and Environmental Research Centre, Institute for Nuclear Research, Debrecen, Hungary

2 Université Paris-Saclay, CNRS, GEOPS, 91405 Orsay, France

3 Aix Marseille Univ, CNRS, IRD, INRA, Coll France, CEREGE, Aix-en-Provence, France

4 Institute of Geosciences and Earth Resources, National Research Council of Italy, Pisa, Italy
5 Laboratory for Heritage Science, Institute for Nuclear Research, Debrecen, Hungary

6 Department of Physics and Geology, University of Perugia, Perugia, Italy

7 Faculty of Environmental Science and Engineering, Babeş-Bolyai University, Cluj-Napoca, Romania

8 Institute of Geography, Faculty of Natural Sciences and Mathematics, Ss. Cyril and Methodius University, Skopje, North Macedonia 


\section{Introduction}

Extensive volcanism characterized the entire Balkan Peninsula since Late Cretaceous-Paleogene times, closely related to the complex tectonic evolution of the Alpine-Mediterranean region (e.g., Boev and Yanev 2001; Cvetković et al. 2004; Harangi et al. 2006; Lustrino and Wilson 2007; Burchfiel et al. 2008). The most intense phase of the volcanism in the central parts of the peninsula occurred during Oligocene times, related to the Dinaride collapse and the retreating Aegean subduction zone (e.g., Boev and Yanev 2001; Cvetković et al. 2004; Pe-Piper and Piper 2007). Several studies focused in detail on this phase of volcanism and its relation to the changes and evolution of the tectonic regime, partly also because of the extensive $\mathrm{Pb}-\mathrm{Zn}$ and $\mathrm{Cu}$ mineralization related to these volcanic rocks (e.g., Serafimovski et al. 2016).

Since the Middle Miocene, the clockwise rotation of the Hellenides along the Scutari-Peć transverse zone, and the westward propagation of the North Anatolian fault zone caused the onset of the Aegean extensional regime. As a consequence, extensional tectonics became dominant also on the central parts of the Balkan Peninsula (e.g., Kissel et al. 1995; Dumurdzanov et al. 2005; Pe-Piper and Piper 2007; Burchfiel et al. 2008; Agostini et al. 2010a, b). The northern boundary of this extensional regime is marked by the Scutari-Peć transverse zone (Fig. 1). This tectonic framework induced a change in the features of volcanism of the region leading to the development of small-volume centers along fault lines and/or boundaries of nappe structures. These volcanic centers concentrated within the Vardar zone and south from Scutari-Peć zone since ca. 6.6 Ma (Fig. 2;

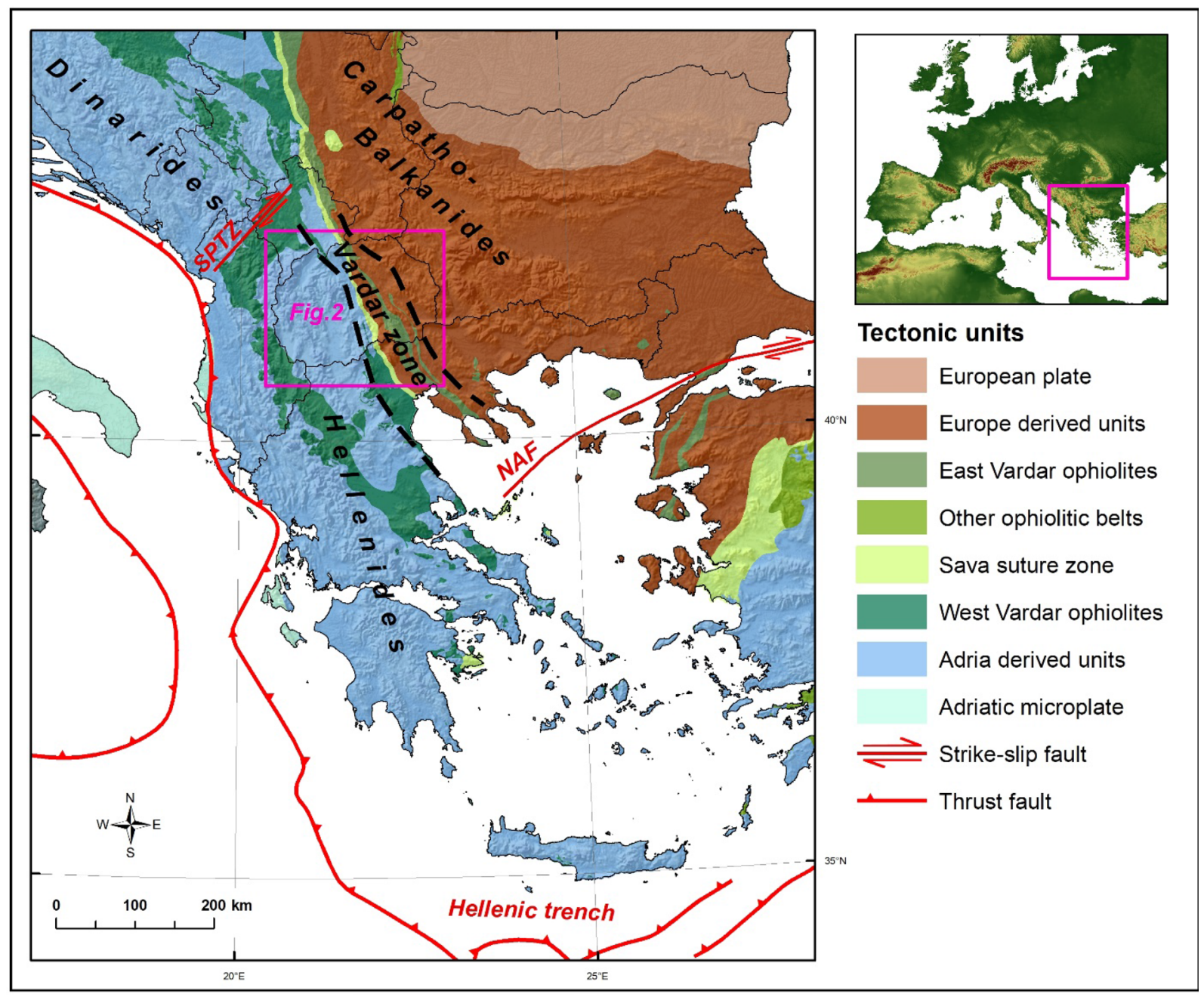

Fig. 1 Geotectonic setting of the studied region between the Dinarides-Hellenides and the Carpatho-Balkanides orogens. NAF-North Anatolian Fault, SPTZ-Skutari-Peć transverse zone. The geo- tectonic unit data are based on Schmid et al. (2020), Vardar zone approximate extent is from Arsovski (1997) 


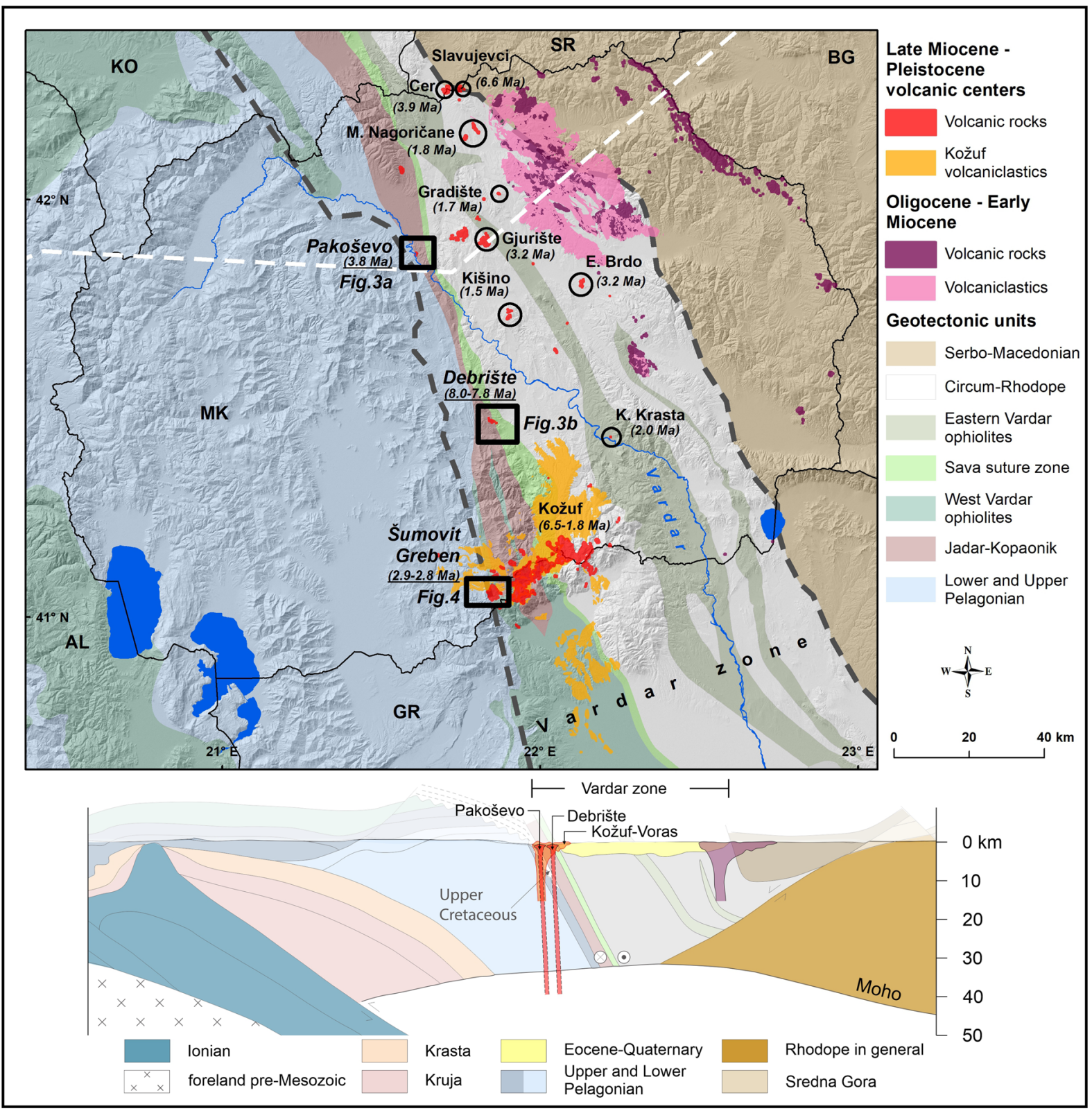

Fig. 2 The Oligocene-Early Miocene and the Late Miocene-Pleistocene volcanic centers in the Vardar zone in the studied area. The sampling locations are marked with rectangles with the newly obtained groundmass $\mathrm{K}-\mathrm{Ar}$ ages (underlined), whereas circles refer to the centers with available age data within the younger phase of volcanism

Cvetković et al. 2004; Yanev et al. 2008a, b). Besides their importance related to the tectonic evolution, these centers are studied in much less detail and received less attention during the past decades compared to similar/neighboring sites (e.g., Pannonian basin: Harangi and Lenkey 2007; Aegean volcanism: Pe-Piper and Piper 2007; Druitt and Vougioukalakis 2019).

Here, we focus on the Late Miocene to Pleistocene volcanism within the Vardar zone, in the central parts of the
(Cvetković et al. 2004; Yanev et al. 2008a). The white dashed line represents the approximate location of the cross section. The cross section is based on Carminati et al. (2004) and Schmid et al. (2020). The positions of the studied volcanic centers are projected onto the cross-sectional line

Balkan Peninsula, bordered by the Scutari-Peć transverse zone on the north (Figs. 1, 2). Yanev et al. (2008a, 2008b) studied in details several of these Late Miocene to Pleistocene small-volume centers (Fig. 2); however, there are still numerous unstudied localities within the region. Three of these are located at or close to the westernmost edge of the Vardar zone: Pakoševo, Debrište and Šumovit Greben centers (Fig. 2). We applied the unspiked Cassignol-Gillot K-Ar technique (Cassignol and Gillot 1982), petrography, 
whole-rock geochemical analyses, and $\mathrm{Sr}$ and $\mathrm{Nd}$ isotopic composition measurements on samples from these localities to unravel the eruptive history of these centers. Their peculiar position can add important details to the understanding of the tectonic and volcanic evolution of the area.

\section{Geological setting}

The central parts of the Balkan Peninsula are located at the junction of the Dinarides-Hellenides and CarpathoBalkanides orogens (Fig. 1). The Dinarides-Hellenides are formed due to the convergence of the Adriatic microplate and the European plate, and the closure of the Neotethys in Late Cretaceous times, which is marked by the Sava suture zone (Fig. 1; Schmid et al. 2020 and references therein). Adria-derived units (e.g., Pelagonian massif) dominate the basement west of the suture zone, together with obducted Western Vardar ophiolites, whereas on the eastern part, Europe-derived units forming the Carpatho-Balkanides (e.g., Serbo-Macedonian massif, Circum-Rhodope), as well as Eastern Vardar ophiolites can be found (Figs. 1, 2; Schmid et al. 2020). The area between the Dinarides-Hellenides and Carpatho-Balkanides orogens is known as the Vardar zone (Kossmat 1924; Arsovski 1997; Dumurdzanov et al. 2005). According to the recent divisions summarized in Schmid et al. (2020), it consists from west to east the Late Cretaceous cover of the Pelagonian massif, the Western Vardar ophiolitic unit, the Adria-derived Jadar-Kopaonik unit, the Sava suture zone and the Circum-Rhodope unit interleaved with the Eastern Vardar ophiolitic unit (Fig. 2). The SWvergent fold-and-thrust belt of the Dinarides-Hellenides orogeny is cut by the SW-NE striking Skutari-Peć transverse zone, along which the Hellenides belt is rotated in a clockwise direction (Kissel et al. 1995; van Hinsbergen et al. 2005). The rotation accelerated in Neogene times associated with the back-arc extension in the Aegean region (Handy et al. 2019; Schmid et al. 2020).

The Cenozoic extension in Macedonia is part of the South Balkan extensional regime, the northern segment of the Aegean extensional regime (Burchfiel et al. 2008). Two periods of extension are identified, in middle to late Eocene and in early Miocene to present time, which were interrupted by a short period of shortening in late Oligocene to early Miocene (Dumurdzanov et al. 2005; Burchfiel et al. 2008). The first period of extension during the Paleogene is interpreted in relation to trench rollback along the northern Hellenic trench. This was followed by shortening related to subduction along the western margins of the Hellenides (Dumurdzanov et al. 2005). The second period of extension is related to the progressive rollback of the subducted slab at the northern Hellenic trench. The Neogene-recent extension is dominated by NW- and E-W-trending faults, the latter being related with the propagation of the North Anatolian fault in the Aegean Sea at ca. 6 Ma (Fig. 1; Dumurdzanov et al. 2005; Burchfiel et al. 2008). This partly decoupled the South Balkan extensional system in the north from the Aegean extensional system in the south, matched by scattered effusive volcanism in the North Aegean (Fytikas et al. 1984; Innocenti et al. 2010). The still-active fault lines and zones are marked by scarps and offsets on Quaternary deposits in the basins, as well as by the locations of numerous earthquakes in recent times. The extension was accompanied by several types of basin formation and associated sedimentation (e.g., true grabens, tilted half-grabens and pull-apart basins along strike-slip faults; Dumurdzanov et al. 2004, 2005).

Extensive volcanism accompanied the tectonic evolution of the region during Cenozoic times. The first period of volcanism occurred during Oligocene-Early Miocene (34-16 Ma) with a peak of magmatism at ca. 33-29 Ma (Boev and Yanev 2001) in the eastern part of the region (Fig. 2), and is marked by the formation of large volcanic complexes with subduction-related geochemical characteristics. The majority of these bodies are eroded to subvolcanic levels, exhibiting a high metallogenic importance (related $\mathrm{Pb}-\mathrm{Zn}$ and $\mathrm{Cu}$ mineralization; e.g., Serafimovski and Boev 1996; Boev and Yanev 2001; Serafimovski et al. 2016).

The second period of volcanism occurred during Late Miocene-Pleistocene times $(<7 \mathrm{Ma})$, and it was constrained to the Vardar zone (Figs. 1,2). This last stage of volcanic activity is largely connected to the tectonic evolution of the South Balkan extensional system. The volcanic centers are located at the edges of the extensional basins, along fault lines or at the boundaries of the different tectonic units and nappe structures, which could act as possible pathways for the upwelling magmas. The onset of the volcanism is related to the Aegean collapse/back-arc extension in the Aegean region and the accelerating clockwise rotation of the Hellenides from Middle/Late Miocene along the Scutari-Peć transverse zone (Kissel et al. 1995). Contrary to the Oligocene large-volume magmatism, mainly small, mafic volcanic centers developed between $6.6 \pm 0.3 \mathrm{Ma}$ and $1.5 \pm 0.1 \mathrm{Ma}$ (Fig. 2; Cvetković et al. 2004; Yanev et al. 2008a). These small centers are formed by small-degree melting of a metasomatised lithospheric mantle source and can be divided into two geochemical groups: $\mathrm{HMg}-\mathrm{K}$ group and UK group, where the latter represents the youngest activity in the region (3.3-1.5 Ma; Yanev et al. 2008a). The only exception for this period is the large Kožuf-Voras volcanic complex (6.5-1.8 Ma; Kolios et al. 1980; Boev et al. 1997) belonging to the LMg-K group of Yanev et al. (2008a), which represents a subduction-related complex located at the border between North Macedonia and Greece (Fig. 2; Boev and Yanev 2001). Several poorly known small volcanic occurrences 
of supposed Late Miocene-Pleistocene age, that may be petrogenetically related to Kožuf-Voras, can be found further to the southeast, mostly along the eastern border of the Vardar zone, both in North Macedonia (e.g. Golema Čuka, Korija, Mrdaja-Dojran) and in Greece (e.g. Doirani, Asprolakkos, Sitsi-Kamen, Strimonikon; Pe-Piper and Piper 2002, 2007). However, for Mrdaja-Dojran, a single K-Ar age of $33 \pm 5 \mathrm{Ma}$ has been reported (Stojanov and Sveshnikova 1985, as cited in Karamata et al. 1992), whereas more recent studies reported zircon $\mathrm{U}-\mathrm{Pb}$ ages of 12-10 Ma for Golema Čuka near Stojakovo (Georgiev et al. 2013; Mitrev and Popov 2021).

Here, we focus on three, previously unstudied volcanic centers located at the western edge of the Vardar zone (Fig. 2). These are from north to south: Pakoševo, Debrište and Šumovit Greben (Figs. 3a, b, 4, respectively). Pakoševo and Debrište represent small-volume centers, whereas Šumovit Greben is a composite volcanic center and the westernmost member of the abovementioned Kožuf-Voras complex.

\section{Analytical methods}

We conducted a field campaign during the summer of 2019 to collect suitable samples, i.e., fresh, unaltered, large (handsize to allow strict selection) blocks at the three localities for general petrography, $\mathrm{K}-\mathrm{Ar}$ geochronology and $\mathrm{Sr}$ and $\mathrm{Nd}$ isotopic studies.

\section{General petrography}

Petrography of the studied samples was performed by combined investigation of a petrographic microscope and a JEOL JSM-IT500HR type SEM equipped with a JEOL EX-74232U1L4Q type EDS detector at the Laboratory for Heritage Science, Institute for Nuclear Research, Debrecen, Hungary. In-situ mineral chemistry of the studied rocks was analyzed using the abovementioned instrument. The analyses were conducted in low vacuum mode (30 Pa) with an accelerating voltage of $15 \mathrm{kV}$, beam current of $3 \mathrm{nA}$, working distance of $10 \mathrm{~mm}$ and counting time of $15-55$ s. Analyses were processed by the JEOL SEM

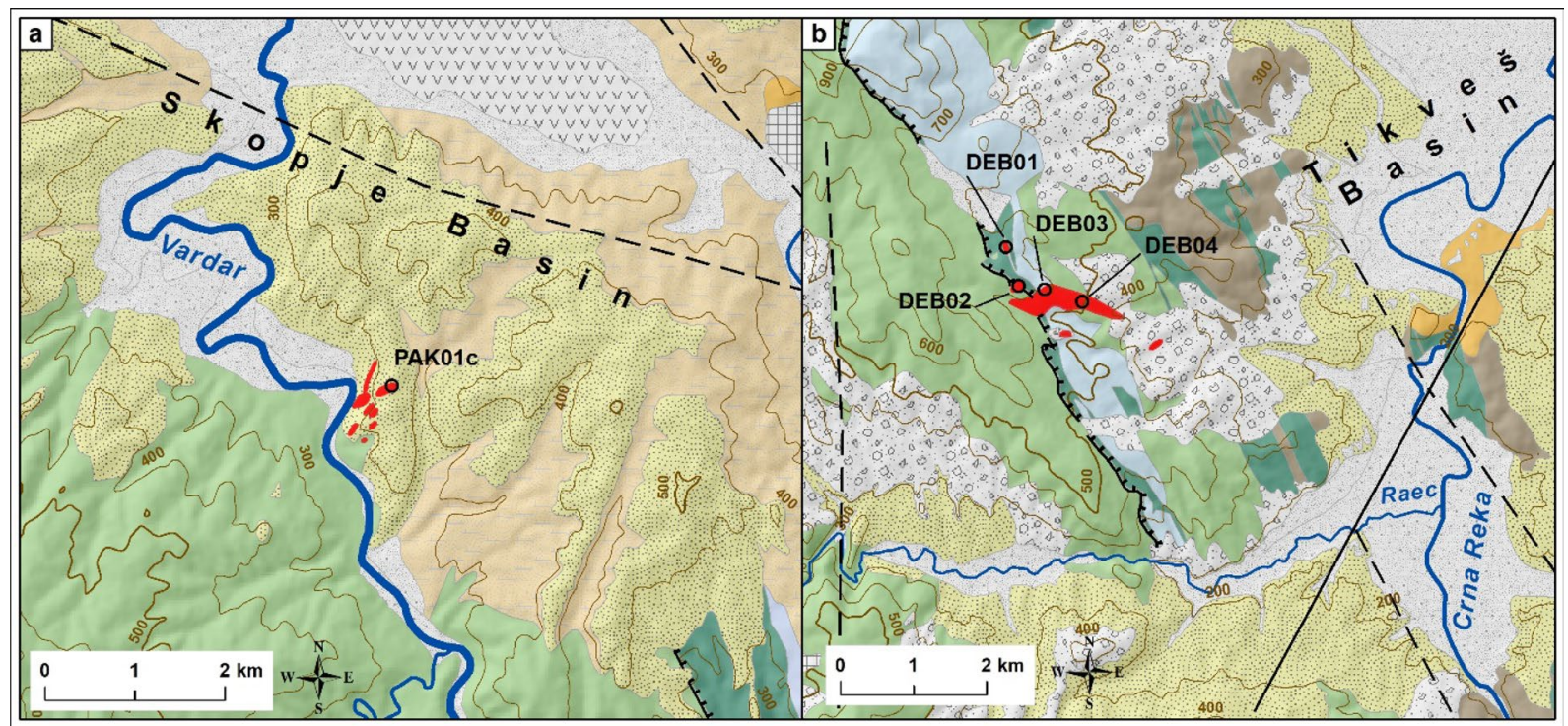

\section{Legend}

\begin{tabular}{|c|c|}
\hline & Alluvial sediments \\
\hline 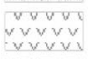 & Swamp sediments \\
\hline \#\#\# & Travertine (Quaternary) \\
\hline $60^{\circ} 0^{\circ}$ & $\begin{array}{l}\text { Breccia and } \\
\text { conglomerates } \\
\text { (Quaternary) }\end{array}$ \\
\hline
\end{tabular}

Gravel, sand, silt (Pliocene)

Clay and sand (Upper Miocene)

Volcanic rocks (MiocenePliocene)

Flysch and limestone (Eocene)

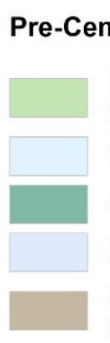

Structures

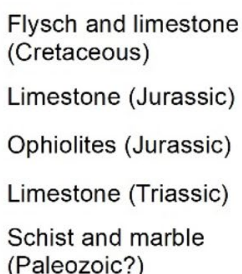

Flysch and limestone

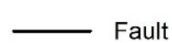

- - Fault - presumed

Thrust

Fig. 3 Sampling locations of Pakoševo (a) and Debrište (b) volcanic centers. Map extents are identical to the corresponding rectangles indicated on Fig. 2. Geological maps are based on Karajovanovik and Hadži-Mitrova (1982) and Rakićević et al. (1973), respectively 


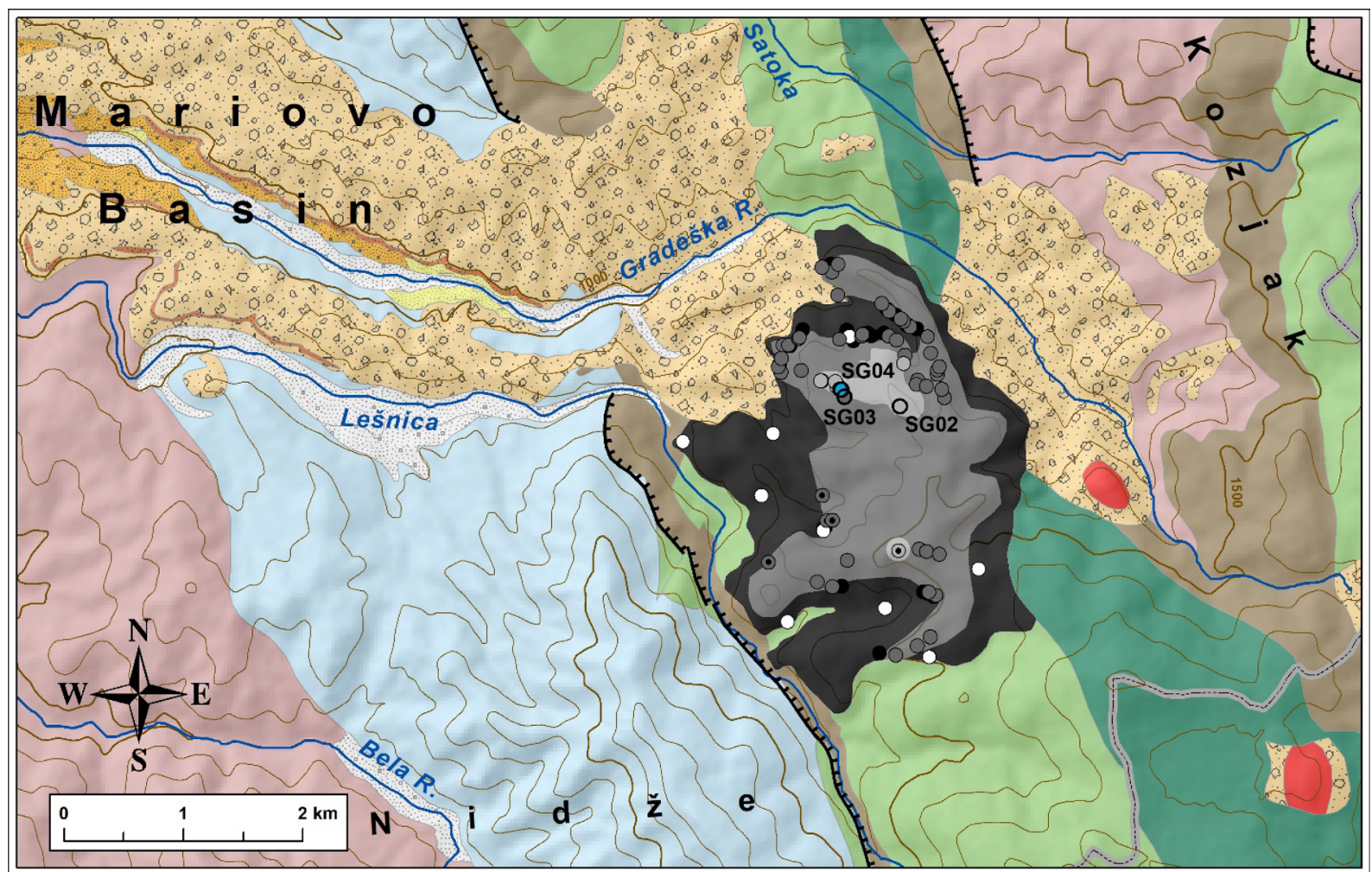

\section{Legend}

\begin{tabular}{l} 
Lithological units \\
Pre-Cenozoic \\
formations \\
\hline Flysch, limestone \\
Ophiolites \\
Marble \\
Schist \\
Gneiss
\end{tabular}

Mariovo Basin sediments
and Kožuf-Voras volcanics
Alluvium
Solcanic breccia
Stratified tuff
Volcanic agglomerates
Volcanic rocks
Gravel, sand, silt
Structures
Thrust

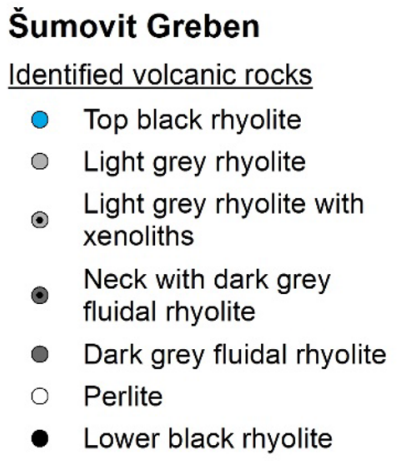

Šumovit Greben

Identified volcanic rocks

- Top black rhyolite

- Light grey rhyolite

Light grey rhyolite with xenoliths

- Neck with dark grey

- fluidal rhyolite

- Dark grey fluidal rhyolite

○ Perlite

- Lower black rhyolite

Fig. 4 Geological map of Šumovit Greben based on Dumurdžanov et al. (1981) and our field observations. The circles mark the sampling locations. Map extent is identical to the corresponding rectangle indicated on Fig. 2

Operation software and the quantification was based on the PRZ method. Field photos of the locations and microscopic photos of the selected samples are presented in the Supplementary Material.

Whole-rock major and trace element geochemical compositions were analyzed at the laboratory of the Mining and Geological Survey of Hungary (Budapest, Hungary). Major elements were determined by ICP-OES, whereas trace elements were analyzed by ICP-MS following a lithium borate fusion and dilution in acid. Detection limits vary between 0.02 and $0.15 \mathrm{wt} \%$ for major elements and $0.05-1 \mathrm{ppm}$ for of trace elements. Results of the analyses are presented in the Supplementary Material.
In the case of Kožuf-Voras, we combined our results of Šumovit Greben with previously published whole-rock geochemical data and classified the volcanic centers of the whole system based on their $\mathrm{K}_{2} \mathrm{O}$ and $\mathrm{SiO}_{2}$ composition. The statistical analysis was done using Hierarchical Cluster Analysis (HCA) in IBM SPSS Statistics 23, on normalized values using Ward's method and Euclidian distances. The compiled dataset, together with the classification is presented in the Supplementary Material. 


\section{Unspiked Cassignol-Gillot K-Ar technique}

Thin section examination was carried out on sampled rocks to identify their textural and petrographic characteristics and to select for dating only those that did not suffer significant alteration. Although larger number of samples was validated as fresh on the field, due to the weathering at microscopic scale (e.g., at grain boundaries), few of them passed the thin section selection and were suitable for dating: one sample at Pakoševo (PAK01c), two at Debrište (DEB01, DEB03) and three at Šumovit Greben (SG02, SG03, SG04) that satisfied our strict selection criteria.

The samples were crushed and sieved to the adequate size fraction $(63-125 \mu \mathrm{m})$ defined for each sample to allow the separation of groundmass from the possibly inherited phenocrysts. It was followed by a $10 \% \mathrm{HNO}_{3}$ acid digestion and cleaning with ionized water in ultrasonic bath. The groundmass fraction was separated from the other phases in heavy liquid and magnetic separator. The homogeneity and purity of the final fraction were checked under the binocular microscope. The prepared groundmass fractions of the volcanic rocks were then dated with the unspiked Cassignol-Gillot K-Ar technique (Cassignol and Gillot 1982; Gillot and Cornette 1986; Gillot et al. 2006), which is wellsuited to date volcanic products over a wide time range with high precision (e.g., Samper et al. 2007; Bablon et al. 2018; Lahitte et al. 2019; Dibacto et al. 2020). Independent K and Ar measurements were performed on the separated, unaltered groundmass fractions in the Laboratoire GEOPS (Geosciences Paris-Saclay, Orsay, France). Following dissolution using a mixture of hydrofluoric, nitric and perchloric acids to break the silicate network, whole potassium content (K) was measured by an Agilent 240 Series AA flame adsorption spectrometer and compared with reference materials
MDO-G (Gillot et al. 1992) and BCR-2 (Raczek et al. 2001), which were prepared and analyzed following the same protocol as the samples. At least two rounds of independent acid attacks and $\mathrm{K}$ measurements were achieved for each sample (Gillot et al. 2006). The K content (Table 1) is considered as final when the relative deviation is less than $1 \%$. Ar isotopic measurements were performed using a multi-collector $180^{\circ}$ sector mass spectrometer (Cassignol and Gillot 1982; Gillot and Cornette 1986; Gillot et al. 2006). K isotopic abundances and ${ }^{40} \mathrm{~K}$ decay constants of Steiger and Jäger (1977) were used. This technique allows accurate detection of percentages of radiogenic $\mathrm{Ar}$ content $\left(\%^{40} \mathrm{Ar} *\right)$ as low as $0.1 \%$ of the total extracted argon (Quidelleur et al. 2001). Details of the Ar isotopic analysis are given by Cassignol and Gillot (1982), Gillot and Cornette (1986), and Gillot et al. (2006). To minimize the effect of mass discrimination, the enrichment of radiogenic argon is calculated from a direct comparison between the instrumental ${ }^{40} \mathrm{Ar} /{ }^{36} \mathrm{Ar}$ sample ratio and the instrumental ${ }^{40} \mathrm{Ar} /{ }^{36} \mathrm{Ar}$ atmospheric ratio at identical pressure immediately after the measurement of Ar isotopic abundance of the sample. Unlike the conventional $\mathrm{K}-\mathrm{Ar}$ technique, this direct quantification does not add a ${ }^{38} \mathrm{Ar}$ spike and is made possible by the very stable analytical conditions. Average relative uncertainties of the ${ }^{40} \mathrm{Ar} /{ }^{36} \mathrm{Ar}$ ratios and on the radiogenic argon are $0.045 \%$ and $2.324 \%$, respectively. The technique relies on the assumption that all of the measured ${ }^{40} \mathrm{Ar} *$ comes from the in-situ radioactive decay of ${ }^{40} \mathrm{~K}$, which requires a strict selection of narrow density range of the groundmass fraction to avoid any contamination by inherited argon from pre-eruption crystallized minerals. At least two independent age determinations were realized for each sample and the final age is obtained as the mean of individual age determinations. The relative uncertainty on each determination is obtained as the

Table 1 Groundmass $\mathrm{K}-\mathrm{Ar}$ ages obtained on samples from the studied volcanic centers

\begin{tabular}{|c|c|c|c|c|c|c|c|c|c|c|}
\hline Sample locality & Sample code & $\mathrm{E}$ & $\mathrm{N}$ & $\mathrm{K} \%$ & $\begin{array}{l}{ }^{40} \mathrm{Ar} * \text { (in } \% \\
\text { of total }{ }^{40} \mathrm{Ar} \text { ) }\end{array}$ & $\begin{array}{l}{ }^{40} \mathrm{Ar} * \text { relative } \\
\text { uncertainty }(\%)\end{array}$ & $\begin{array}{l}{ }^{40} \mathrm{Ar}^{*} \\
\left(\times 10^{13}\right. \\
\text { at/g })\end{array}$ & Age (Ma) & $\pm 1 \sigma$ & $\begin{array}{l}\text { Weighted } \\
\text { mean } \pm 1 \sigma \\
(\mathrm{Ma})\end{array}$ \\
\hline \multirow[t]{6}{*}{ Šumovit Greben } & SG02 & 21.86137 & 41.06154 & 4.979 & 75.35 & 0.133 & 1.511 & 2.90 & 0.04 & $2.89 \pm 0.04$ \\
\hline & & & & & 63.03 & 0.159 & 1.500 & 2.88 & 0.04 & \\
\hline & SG03 & 21.85591 & 41.06232 & 5.092 & 54.67 & 0.183 & 1.521 & 2.86 & 0.04 & $2.87 \pm 0.04$ \\
\hline & & & & & 54.86 & 0.182 & 1.540 & 2.89 & 0.04 & \\
\hline & SG04 & 21.85557 & 41.06286 & 5.023 & 70.26 & 0.142 & 1.450 & 2.76 & 0.04 & $2.78 \pm 0.04$ \\
\hline & & & & & 67.21 & 0.149 & 1.465 & 2.79 & 0.04 & \\
\hline \multirow[t]{2}{*}{ Pakoševo } & PAK01c & 21.62430 & 41.87108 & 3.817 & 5.60 & 1.787 & 1.528 & 3.83 & 0.09 & $3.77 \pm 0.09$ \\
\hline & & & & & 5.54 & 1.806 & 1.480 & 3.71 & 0.09 & \\
\hline \multirow[t]{4}{*}{ Debrište } & DEB01 & 21.84948 & 41.47503 & 4.892 & 93.62 & 0.107 & 3.991 & 7.79 & 0.11 & $7.8 \pm 0.1$ \\
\hline & & & & & 91.55 & 0.109 & 3.962 & 7.74 & 0.11 & \\
\hline & DEB03 & 21.85568 & 41.46982 & 4.398 & 80.58 & 0.124 & 3.711 & 8.06 & 0.11 & $8.0 \pm 0.1$ \\
\hline & & & & & 78.55 & 0.127 & 3.637 & 7.90 & 0.11 & \\
\hline
\end{tabular}


quadratic sum of all independent sources of uncertainty, i.e., the $\mathrm{K}$ content (1\%), the calibration of the mass spectrometer $(1 \%)$, and the amount of radiogenic argon (e.g., Quidelleur et al. 2001; Gillot et al. 2006; Lahitte et al. 2019). Ages are reported with $1 \sigma$ level uncertainties in Table 1.

\section{Sr and Nd analyses}

The $\mathrm{Sr}$ and $\mathrm{Nd}$ isotope analyses were carried out at the Istituto di Geoscienze e Georisorse-CNR of Pisa (Italy) on six samples, using a ThermoFisher Neptune Plus MC-ICP-MS, in $2 \% \mathrm{HNO}_{3}$ solution containing $20-200 \mathrm{ng} \mathrm{g}^{-1}$ of analyte. Some of the samples, in particular DEB01 and PAK01c, had high LOI contents and petrographic evidences of secondary phases, such as carbonate amygdales. For this reason, samples were leached in hot, $6.6 \mathrm{~N} \mathrm{HCl}$ for half an hour, then the supernatant solution was removed, and powders were rinsed five times with ultrapure $\mathrm{H}_{2} \mathrm{O}$. The remaining material was digested with $\mathrm{HF}+\mathrm{HNO}_{3}$ and re-dissolved with $\mathrm{HCl}$. $\mathrm{Sr}$ and $\mathrm{Nd}$ were extracted from the matrix in class $100(\mathrm{Sr})$ and class $1000(\mathrm{Nd})$ clean rooms, after conventional cation-ion exchange techniques. Sr analyses were corrected for mass bias fractionation using the ${ }^{88} \mathrm{Sr} /{ }^{86} \mathrm{Sr}$ ratio $(=8.375209)$ and for mass interference using the ratios ${ }^{83} \mathrm{Kr} /{ }^{84} \mathrm{Kr}$ $(=0.201750),{ }^{83} \mathrm{Kr} /{ }^{86} \mathrm{Kr}(=0.664740)$ and ${ }^{85} \mathrm{Rb} /{ }^{87} \mathrm{Rb}$ $(=2.592310)$. The analytical accuracy and long-term external reproducibility for ${ }^{87} \mathrm{Sr} /{ }^{86} \mathrm{Sr}$ of reference material NIST SRM 987 was $0.710251 \pm 12(n=38)$. Instrumental mass fractionation during $\mathrm{Nd}$ analyses was corrected using the ${ }^{146} \mathrm{Nd} /{ }^{144} \mathrm{Nd}$ ratio $(=0.7219)$. Mass interference correction was done using the ratios ${ }^{147} \mathrm{Sm} /{ }^{144} \mathrm{Sm}(=4.838710)$, and ${ }^{147} \mathrm{Sm} /{ }^{148} \mathrm{Sm}(=1.327400)$. The analytical accuracy and long-term external reproducibility for ${ }^{143} \mathrm{Nd} /{ }^{144} \mathrm{Nd}$ of reference material J-Ndi- 1 was $0.512098 \pm 5(n=17)$. Full analytical details can be found in Lustrino et al. (2020).

\section{Results}

Since the three sampling localities differ in character, we present the basic volcanological features, $\mathrm{K}-\mathrm{Ar}$ ages and the obtained petrographic, whole-rock geochemistry and $\mathrm{Sr}-\mathrm{Nd}$ isotopic results for each locality separately.

\section{Pakoševo}

Located at the southeastern edge of the Skopje basin (Figs. 2, 3a), the volcanic center of Pakoševo is composed of a central massive, unsorted tuff deposit with lithic clasts, possibly a remnant of a diatreme breccia deposit, related to a phreatic/phreatomagmatic eruption with additional remnants of small-volume lava flows. They are covering the Pliocene sediments that belong to the Solnje Formation
(Dumurdzanov et al. 2004). The age of this volcanic center was assigned to Pleistocene based on its stratigraphic position and correlation with similar settings in the neighboring basins, as indicated by the geological mapping and description of Karajovanovik and Hadži-Mitrova (1982). The studied sample (PAK01c), collected from a remnant of the lava flow, has dark grey color and mainly aphanitic texture with amygdales.

The sampled lava rock is a basaltic trachyandesite (52 wt $\% \mathrm{SiO}_{2}, 3.7$ wt $\% \mathrm{Na}_{2} \mathrm{O}$ and 3.7 wt $\% \mathrm{~K}_{2} \mathrm{O}$; Fig. 5), which is part of the shoshonitic series based on its elevated $\mathrm{K}$ content (Peccerillo and Taylor 1976) and of the HMg-K group $(\mathrm{MgO}>5 \mathrm{wt} \%$; 6.6-3.2 Ma) of Yanev et al. (2008a). It has a porphyritic texture with a hypocrystalline groundmass and amygdales of carbonates, where the phenocrysts are clinopyroxene, mica and altered olivine. The microlithic groundmass is composed of mainly alkali feldspar, clinopyroxene and Fe-Ti oxides. Besides the magmatic phases, large number of crustal xenoliths (mainly sandstone/quartzite) and secondary carbonates can be identified within the sample. The clinopyroxene assemblage has a uniform major element composition $\left(\mathrm{En}_{47-49} \mathrm{Wo}_{45-47}\right.$; diopside) together with $\mathrm{Mg} \#$ of 0.89-0.91 (expressed as $\mathrm{Mg} /\left(\mathrm{Mg}+\mathrm{Fe}^{\mathrm{tot}}\right)$ ). The wholerock composition of the sample shows enrichment of the large ion lithophile (LIL) elements (e.g., Cs, Ba, K) and light rare-earth elements (LREE) relative to the high field strength (HFS) elements (e.g., Nb, Ti) and heavy rare-earth elements (HREE), respectively. There is a positive $\mathrm{Pb}$ anomaly and no negative Eu-anomaly, which are also characteristic for the other $\mathrm{HMg}-\mathrm{K}$ group centers (Fig. 5). The $\mathrm{Ba} / \mathrm{Nb}$ and $\mathrm{Sr} / \mathrm{Y}$ ratios are relatively high (141 and 77, respectively) compared to the other $\mathrm{HMg}-\mathrm{K}$ centers (Fig. 5). The ${ }^{87} \mathrm{Sr} /{ }^{86} \mathrm{Sr}$ and ${ }^{143} \mathrm{Nd} /{ }^{144} \mathrm{Nd}$ ratios $(0.709593$ and 0.512257 , respectively; Fig. 5) are considered as primary features of the samples, given that the secondary phases were mechanically and chemically removed prior to isotope analysis.

The sample was successfully dated with $\mathrm{K}$ content of the groundmass of $3.8 \mathrm{wt} \%$ and low value of radiogenic argon (5.6\%, Table 1), which could mean that even after the strict selection, slightly altered groundmass is still present. This causes higher uncertainty for the age of this sample. However, based on our field and petrographic observations, this sample is still the most suitable one amongst the collected samples. The obtained age on the lava flow at Pakoševo, the northernmost studied center is $3.77 \pm 0.09 \mathrm{Ma}$ (Table 1 ).

\section{Debrište}

Debrište is located at the western edge of the Tikveš basin, where we identified at least three possible centers (hereafter labelled as DEB01, DEB02 and DEB03; Fig. 3b). DEB02 and DEB03 centers align along a W-E direction, whereas DEB01 center is located northward of them. DEB01 crops 

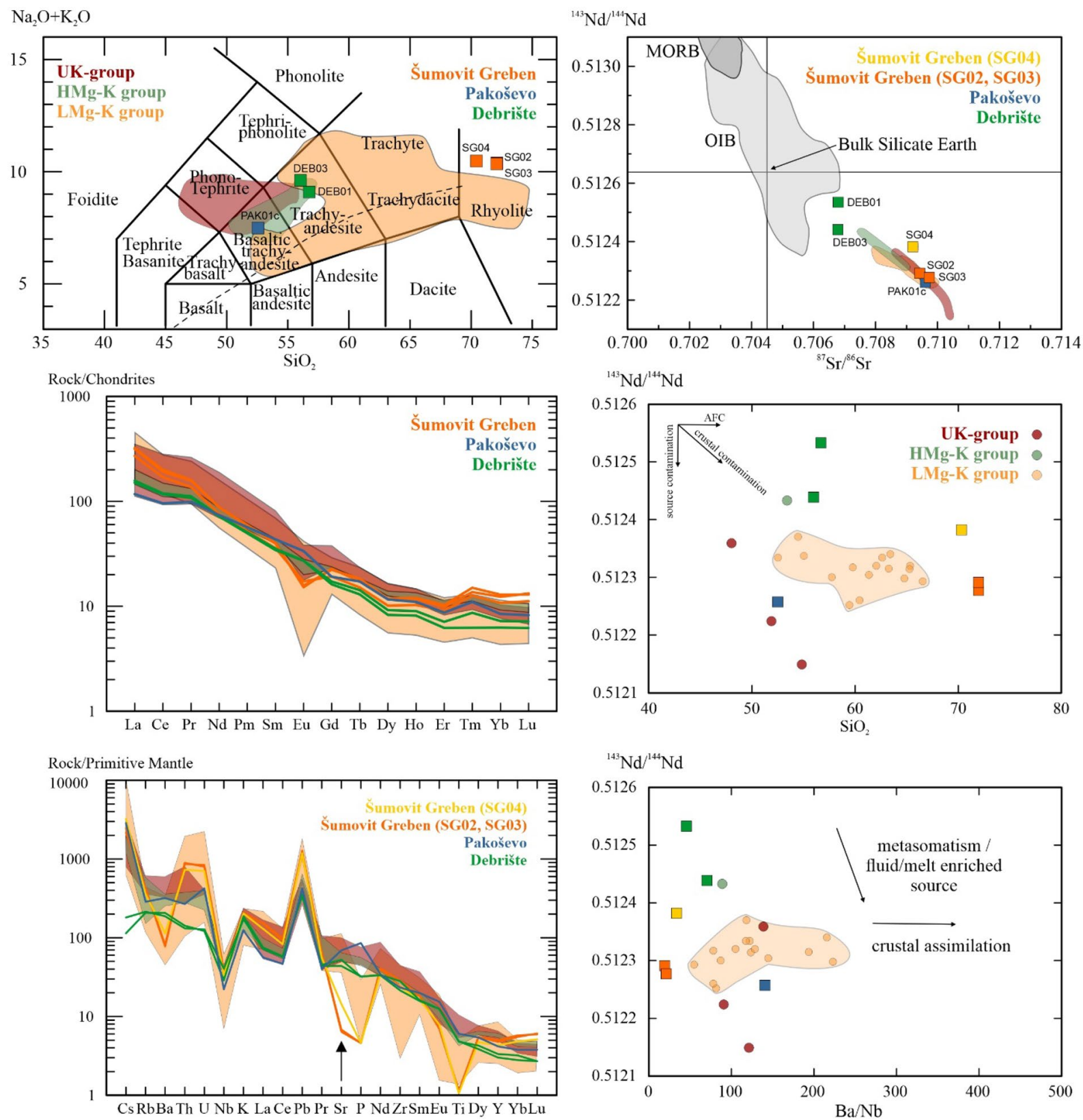

Fig. 5 Whole-rock major element diagram, trace element characteristics and $\mathrm{Sr}$ and $\mathrm{Nd}$ isotopic composition of the studied samples compared to previously published results (Eleftheriadis et al. 2003; Yanev et al. 2008a). Total alkali-silica diagram (Le Bas et al. 1992) and chondrite-normalized rare-earth elements (REE) and primi-

out only in a limited area at the contact of Jurassic limestone and ophiolite (mainly serpentinite) units, whereas DEB02 and DEB03 covers a larger area where besides the lava rocks, scarce scoriae are also present. Both DEB02 and DEB03 occur at an elevated position compared to the local topography and at both locations the outcropping rocks exhibit circular, concentric features (Supplementary Material). Additionally, small-volume lava flows can be traced tive mantle-normalized trace element plots (normalizing values after Nakamura 1974 and Sun and McDonough 1989, respectively). Bulk Silicate Earth value and MORB and OIB fields are from Zindler and Hart (1986). The arrow on the trace element panel (bottom left) highlights the different $\mathrm{Sr}$ depletion in the Šumovit Greben samples

from DEB03 center towards the east (DEB04 on Fig. 3b). Its age was considered as Pleistocene according to the geological mapping and description (Rakićević et al. 1973), covering sediments of the Tikveš basin stratigraphically assigned as Pleistocene. DEB01 exhibits dark grey colored, aphanitic texture with biotite as the recognizable phenocryst, whereas DEB03 is light grey, also has an aphanitic texture with elongated vesicules but without the presence of biotite. DEB02 
and DEB04 samples exhibit similar macroscopic features as DEB03 however, due to their more altered character these were not studied in more details.

The two studied samples from Debrište (DEB01 and DEB03) are trachyandesite (55-56 wt $\% \mathrm{SiO}_{2}, 3.6-3.9 \mathrm{wt} \%$ $\mathrm{N}_{2} \mathrm{O}$ and 5.2-5.6 wt $\% \mathrm{~K}_{2} \mathrm{O}$; Fig. 5), that would fit within the LMg-K group $(\mathrm{MgO}<5 \mathrm{wt} \% ; 6.5-1.8 \mathrm{Ma})$ of Yanev et al. (2008a), represented solely by the Kožuf-Voras volcanic system. However, apart from their slightly lower $\mathrm{MgO}$ content (4.0 wt \%), the Debrište samples exhibit similarities with the geochemical characteristics of the HMg-K group of Yanev et al. (2008a; Fig. 5).

Despite similar whole-rock compositions (Fig. 5), the two studied samples show some differences in their petrography. DEB01 sample, the westernmost center at this locality, has a porphyritic texture with hypocrystalline groundmass, where clinopyroxene, biotite and partly altered olivine are the main phenocrysts. The groundmass is composed of clinopyroxene, feldspar and Fe-Ti oxides. The clinopyroxene assemblage has a relatively uniform major element composition $\left(\mathrm{En}_{41-50} \mathrm{Wo}_{42-47}\right.$; diopside-augite) together with $\mathrm{Mg} \#$ of $0.77-0.85$. The texture of DEB03 is porphyritic with intergranular groundmass, where olivine is the dominant phenocryst, which rims are partly altered to iddingsite. The groundmass is composed dominantly of clinopyroxene. The olivine crystals exhibit normal, progressive zoning, with cores having higher $\mathrm{Fo}\left(\mathrm{Fo}_{80}\right)$ content and $\mathrm{Mg \#}(0.80)$ and rims with lower $\mathrm{Fo}\left(\mathrm{Fo}_{66-70}\right)$ and $\mathrm{Mg \#}(0.68-0.70)$ and higher $\mathrm{CaO}$ content. The clinopyroxene crystals are slightly more $\mathrm{Mg}$-rich compared to the DEB01 sample $\left(\mathrm{En}_{43-50} \mathrm{Wo}_{42-45}\right.$; augite) with $\mathrm{Mg} \#$ of $0.79-0.88$. Although the whole-rock composition shows enrichment of LIL elements relative to the HFS elements, these samples are the least enriched in LIL and most depleted in HFS and HRE elements amongst the $\mathrm{HMg}-\mathrm{K}$ centers (Fig. 5) exhibiting also the lowermost $\mathrm{Ba} / \mathrm{Nb}$ and $\mathrm{Rb} / \mathrm{Nb}$ ratios (46 and 5, respectively; Fig. 5). Their $\mathrm{Nd}$ and $\mathrm{Sr}$ isotope compositions exhibit very little variability with ${ }^{143} \mathrm{Nd} /{ }^{144} \mathrm{Nd}$ and ${ }^{87} \mathrm{Sr} /{ }^{86} \mathrm{Sr}$ ratios $(0.512530$ and 0.706749 for DEB01; 0.512436 and 0.706753 for DEB03, respectively).

DEB03 and DEB01 samples were successfully dated with $\mathrm{K}$ content of the groundmass of 4.4 and $4.9 \mathrm{wt} \%$, and ${ }^{40} \mathrm{Ar} *$ of 78.6 and $93.6 \%$, respectively (Table 1). Amongst the dated samples in this study, Debrište center is the oldest, with obtained ages for DEB01 and DEB03 of $7.8 \pm 0.1 \mathrm{Ma}$ and $8.0 \pm 0.1 \mathrm{Ma}$, respectively. While DEB01 and DEB03 exhibit petrographic and geochemical differences, the other samples from this locality (DEB02 center and DEB04 flow) show similarities to the DEB03 sample. It may thus indicate an approximately synchronous formation for these three units. Although the eruption ages overlap at $2 \sigma$ level $(95 \%$ confidence interval), the ages together with field and petrographic characteristics, indicate that the DEB02, DEB03 centers and DEB04 lava flow, formed at ca. $8 \mathrm{Ma}$, followed by the extrusion of the DEB01 lava flow in a very restricted area at ca. 7.8 Ma.

\section{Šumovit Greben}

Šumovit Greben is a rhyolitic volcanic center, located at the southeast edge of the Mariovo basin between Kozjak and Nidže Mts., and it is the westernmost center of the KožufVoras volcanic system, which extends in SW-NE direction along the state border between North Macedonia and Greece (Figs. 2, 4, 6). Kožuf-Voras forms numerous distinct centers, lava domes and related flows, and various types of pyroclastic rocks (pyroclastic flow- and fall-out deposits), which deposited in the Tikveš and Mariovo basins in the north and northwest, respectively, and in the Almopia and Thessaloniki basins in the south (Boev and Yanev 2001; Vougioukalakis 2002). Its activity occurred at ca. 6.5-1.8 Ma (Kolios et al. 1980; Boev et al. 1997), which had several divisions according to the different authors, working separately on both sides of the border. Boev and Yanev (2001) distinguished a high-Mg shoshonitic to trachydacitic group and an andesitic-dacitic-rhyolitic group in the Kožuf area, whereas Eleftheriadis et al. (2003) differentiated an east-central western and a southwestern group in the Voras area. Four large explosive events were identified producing ash and tephra layers deposited in the Almopia and Thessaloniki basins on the south. While there are no available age data for the oldest one, the younger ones occurred at $4.9 \mathrm{Ma}, 4.2 \mathrm{Ma}$ and 2.6 Ma (Eleftheriadis and Vougioukalakis 2006). Available Ar-Ar data of tuff deposits on the northern side from the Vitačevo plateau (Tikveš basin) yield similar ages of $5.1 \pm 0.1 \mathrm{Ma}$ and 4.1 $\pm 0.7 \mathrm{Ma}$ (Lippolt and Fuhrmann 1986; Neubauer et al. 2009); however, the northern and southern pyroclastic occurrences have not been correlated yet.

Despite the numerous studies on the Kožuf-Voras volcanic system in the last forty years (e.g., Kolios et al. 1980; Boev et al. 1997; Boev and Yanev 2001; Vougioukalakis 2002; Eleftheriadis et al. 2003; Yanev et al. 2008a), the westernmost Šumovit Greben center remained unstudied. Here, four units were identified during fieldwork based on the differences in lithology, and an updated map of the volcanic formations of the Sumovit Greben center is presented (Fig. 4; Supplementary Material). The lowermost one ('lower black rhyolite'; Fig. 4) outcrops only at the outer parts of the center and consists of black glassy porphyritic rhyolite and perlite. This unit is highly eroded and altered; however, its original forms, i.e., foliated fabric, brecciated and folded flow remnants are still visible at few places. It is followed by the so-called dark grey foliated rhyolite (sample SG03; Fig. 4), which builds up the majority of the center. This unit is followed by light grey rhyolite (sample SG02; Fig. 4), which does not exhibit any foliations, crops 


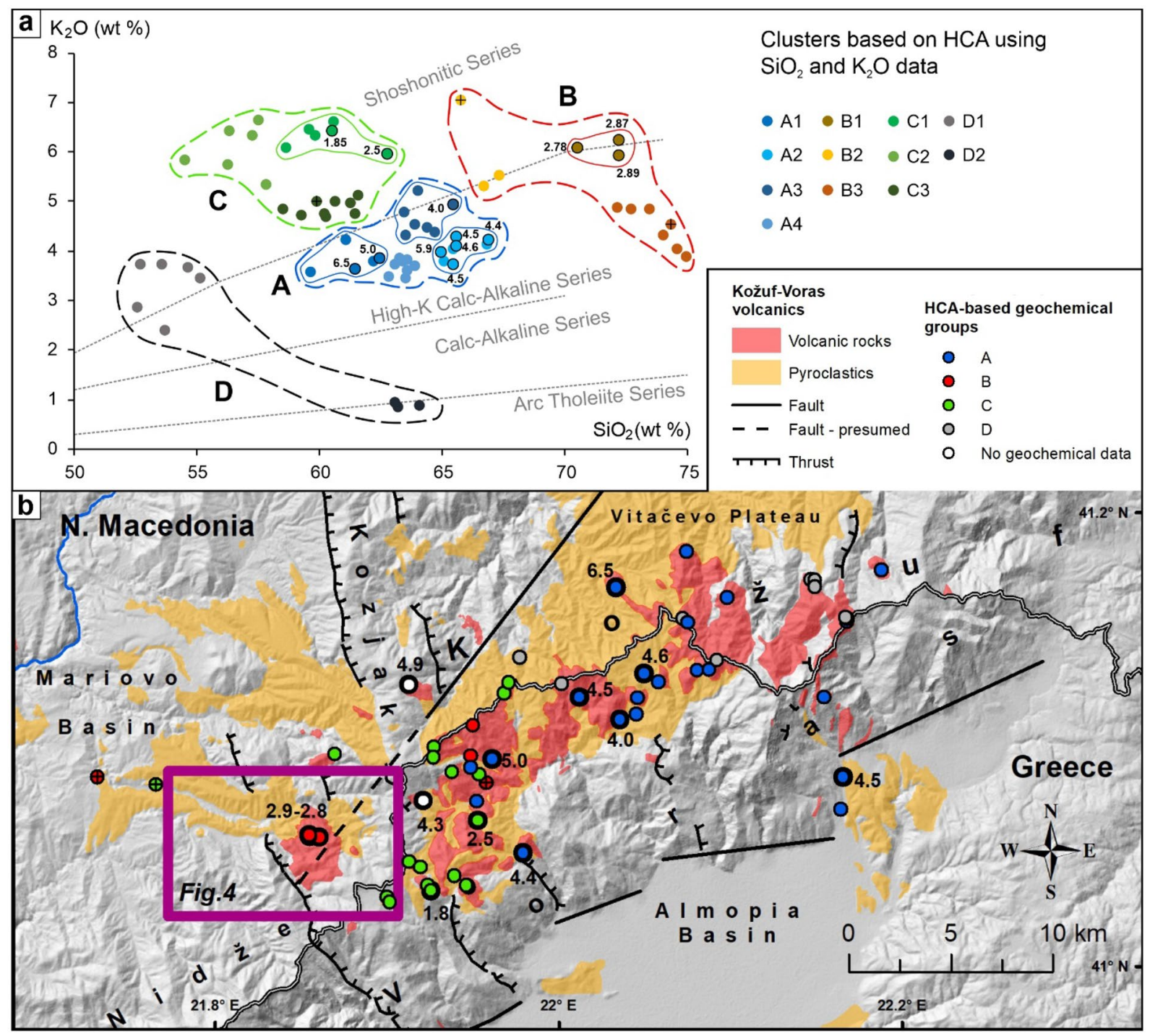

Fig. 6 Results of the hierarchical cluster analyses (HCA) on the available whole-rock geochemical data for the Kožuf-Voras volcanic system: a the distribution of the clusters based on their $\mathrm{K}_{2} \mathrm{O}-\mathrm{SiO}_{2}$ (wt\%) composition (after Peccerillo and Taylor 1976); b spatial distribution of the sites with known locations, color coded accordingly to the four

out only at restricted places, and at some places contains cognate lithics of the dark grey foliated rhyolite. On the top of the succession, at a restricted area in the northern part of the center, a black glassy porphyritic rhyolite can be found (sample SG04; 'top black rhyolite' in Fig. 4). Additionally, remnants of a neck structure/feeding dyke can be identified in the central area (Fig. 4) exhibiting vertical fluidal/foliated structure. Although every mapped unit was sampled, the lowermost one was not studied in more details due to its altered characteristics.

All of the studied samples are rhyolites $\left(>70 \mathrm{wt} \% \mathrm{SiO}_{2}\right.$, 4.1-4.3 wt $\% \mathrm{~N}_{2} \mathrm{O}$ and 5.9-6.3 wt $\% \mathrm{~K}_{2} \mathrm{O}$; Fig. 5) and belong to the high-K-shoshonitic series and the $\mathrm{LMg}-\mathrm{K}$ group
HCA-based groups. Circles with thick black outlines refer to locality with available ages, whereas circles with crosses refer to pyroclastic samples. The complete dataset is available in the Supplementary Material

( $<5 \mathrm{wt} \% \mathrm{MgO}$ ) of Yanev et al. (2008a). Šumovit Greben samples exhibit similarities in their whole-rock characteristics to volcanic rocks of the other Kožuf-Voras centers, but the rhyolitic composition and the very low Sr content $(<500 \mathrm{ppm})$ make them unique within the Kožuf-Voras volcanic system. The samples, besides their macroscopic differences (foliated, non-foliated, glassy), have some petrographic/mineralogical differences, as well. The phenocrysts of the light grey (SG02) and dark grey (SG03) rhyolites are dominantly K-feldspar, quartz and plagioclase with amphibole and biotite as the main mafic minerals and titanite (and Fe-Ti oxides) as the most abundant accessory phase. SG02 has a devitrified groundmass without foliation, whereas 
SG03 exhibits foliation with both devitrified and glassy groundmasses. The top black rhyolite (SG04), which is found at the stratigraphically highest position, has a perlitic texture, lacks quartz and contains abundant clinopyroxene as the main mafic phase with a glassy groundmass. It consists of aggregates of plagioclase, K-feldspar, clinopyroxene and biotite. The whole-rock composition of the samples show enrichment in LIL elements (except Ba), U, Th and $\mathrm{Pb}$ relative to some of the HFS elements $(\mathrm{Nb}, \mathrm{Ti}), \mathrm{Sr}$ and $\mathrm{P}$. All samples exhibit a negative Eu-anomaly (Fig. 5). SG04 sample is less depleted in $\mathrm{Sr}$ compared to SG02 and SG03 samples (Fig. 5). The $\mathrm{Nd}$ and $\mathrm{Sr}$ isotopic compositions for the lower units (SG02 and SG03) are similar to each other (0.512291-0.512277 and 0.709431-0.709735, respectively), whereas the SG04 sample exhibits higher ${ }^{143} \mathrm{Nd} /{ }^{144} \mathrm{Nd}$ and lower ${ }^{87} \mathrm{Sr} /{ }^{86} \mathrm{Sr}$ ratio (0.512382 and 0.709208 , respectively) compared to the other two studied samples.

Šmovit Greben samples were successfully dated with $\mathrm{K}$ content of the groundmass of 5.0-5.1 wt\% and ${ }^{40} \mathrm{Ar}^{*}$ content ranging of 54.7 to $75.3 \%$ (Table 1). The obtained eruption ages of $2.89 \pm 0.04 \mathrm{Ma}$ and $2.87 \pm 0.04 \mathrm{Ma}$, for the light grey rhyolite (SG02) and the dark grey foliated rhyolite (SG03), respectively, are statistically indistinguishable from each other. These two units formed at ca. 2.9 Ma, whereas the uppermost glassy, porphyritic rhyolite (SG04) represents a younger phase, although it still slightly overlaps within uncertainties with the other two samples, having an eruption age of $2.78 \pm 0.04 \mathrm{Ma}$. Based on the obtained ages, Šumovit Greben is the youngest amongst our studied volcanic centers.

\section{Discussion}

\section{Formation of Debrište and Pakoševo volcanic centers}

The volcanism at Debrište was considered as part of the youngest phase of volcanism, as it was assigned a Pleistocene age based on the stratigraphic relationships (Rakićević et al. 1973). However, both our field observations and the groundmass $\mathrm{K}-\mathrm{Ar}$ ages are in contrast with this assumption. The centers and lava flows do not cut through nor cover Cenozoic sedimentary deposits, but only the Jurassic and Cretaceous rocks which have been assigned to the Jadar-Kopaonik unit (Schmid et al. 2020). The outcropping volcanic rocks at DEB02 and DEB03 centers exhibit a concentric character in their appearance, which suggests that it is an already slightly eroded level of the volcano. The scarce presence of scoriae and the nearby well-preserved lava flows suggest that the volcanic activity at these centers exhibited both explosive and effusive eruptions. Pieces of the lava flows can be found in contact with younger (presumably Quaternary) sediments as eroded blocks. The newly obtained $\mathrm{K}-\mathrm{Ar}$ age yielded $8.0 \pm 0.2 \mathrm{Ma}$ for the DEB03 center and a somewhat younger, 7.8 $\pm 0.2 \mathrm{Ma}$ for DEB01 center which supports our field observations. These ages show that instead of Pleistocene age, Debrište is actually the oldest known center within the Late Miocene-Pleistocene volcanism of the wider region (south from the Scutari-Peć transverse zone).

The HMg-K group represents the older phase (6.6-3.2 Ma; Cvetković et al. 2004; Yanev et al. 2008a) of the Late Miocene to Pleistocene small scattered volcanism in the area. Debrište has slightly lower $\mathrm{MgO}$ content (4.0 wt\%) to be assigned to this group ( $>5 \mathrm{wt} \%$; Yanev et al. 2008a). However, based on similar features regarding its extent, phenocrysts content, trace and rare-earth element pattern (Fig. 5), this volcanic center can be considered as part of, and the oldest member of the HMg-K group.

Volcanic activity on the northernmost studied center, Pakoševo occurred at $3.8 \pm 0.2 \mathrm{Ma}$ based on the newly obtained groundmass $\mathrm{K}-\mathrm{Ar}$ age (Table 1). Here, the volcanism was characterized by a phreatic eruption which formed a diatreme breccia, followed by small-volume lava flows covering the Pliocene coarse-grained sediments of the Solnje Formation. The lava rocks contain amygdales filled with secondary carbonates indicating that the lava flows deposited in a subaquatic environment, which is in agreement with the alluvial to lacustrine depositional environment of Solnje Formation (Dumurdzanov et al. 2004). It also contains a large number of crustal xenoliths (mainly quartzite). The association of the Pakoševo volcanic center with the sediments of the Solnje Formation makes the 3.8 Ma groundmass $\mathrm{K}-\mathrm{Ar}$ age the first radiometric age for the Solnje Formation in Skopje basin, which was previously assigned to Pliocene based on correlation with the same formation in the nearby Kumanovo basin (Dumurdzanov et al. 2004). Its petrological, geochemical features, and the obtained age are very similar to other centers of the $\mathrm{HMg}-\mathrm{K}$ group. Gjurište, another small $\mathrm{HMg}-\mathrm{K}$ center having similar features as Pakoševo, located ca. $15 \mathrm{~km}$ to the northeast (Fig. 2), was formed relatively close in time $(3.2 \pm 0.1 \mathrm{Ma}$; Yanev et al. 2008a) and space. It marks this area as volcanically active during the 4-3 Ma period.

\section{The rhyolitic Šumovit Greben center}

Šumovit Greben is the southernmost center and the youngest one within the studied localities. Based on the newly obtained groundmass $\mathrm{K}-\mathrm{Ar}$ ages, volcanic activity is restricted here to a narrow interval (2.9-2.8 Ma), which falls within the quite wide range of previously dated volcanic rocks of the Kožuf-Voras massif (6.5-1.8 Ma; Kolios et al. 1980; Boev et al. 1997), and it is the youngest dated center within the Kožuf part. 
Since different classifications of the volcanic rocks existed on both sides of the border for the Kožuf-Voras system, we present here a unified classification based on the available whole-rock geochemical data. Based on our Hierarchical Cluster Analyses (HCA) of the available wholerock data on Kožuf-Voras, we identified twelve clusters aggregated into four main groups (labeled A to D in Fig. 6). Despite the few available geochronological data, for three of the main groups, radiometric ages are available. All of the older dated centers (6.5-4.0 Ma) fall into group A composing mainly the eastern part of the Kožuf-Voras massif (A1, A2 and A3 clusters; Fig. 6). The youngest dated centers, as well as several undated localities, belong to group $\mathrm{C}$ characterized by elevated $\mathrm{K}_{2} \mathrm{O}$ content and located mainly on the southwestern part of the system (Fig. 6). Šumovit Greben center, with few other localities, group separately from the two abovementioned ones, with somewhat in between eruption age and $\mathrm{K}_{2} \mathrm{O}$ content (group B; Fig. 6). The fourth group has a distinct, more mafic geochemical composition compared to the other centers, with no available age data (group D; Fig. 6). Some members of this group are likely present as enclaves (e.g., Vougioukalakis 1994; Eleftheriadis et al. 2003), which cannot be excluded for the other members either, or they might represent an older, more eroded phase. The general trend for the whole Kožuf-Voras system is the progressive age decrease towards southwest in line with an increase in $\mathrm{K}_{2} \mathrm{O}$ content as also noted by Vougioukalakis (1994) for the Voras side.

Šumovit Greben is the only center with rhyolitic composition within this volcanic system. It has a very low $\mathrm{Sr}$ content compared to the other centers and shows a rareearth element pattern (Fig. 5) similar to cold-wet-oxidized rhyolites, which is characteristic for the subduction zone rhyolites (Bachmann and Bergantz 2009). The negative $\mathrm{Ba}, \mathrm{Sr}, \mathrm{Ti}$ and $\mathrm{Eu}$ anomaly and the rarity of the plagioclase phenocrysts (except for SG04) suggest extensive removal of plagioclase, whereas the extremely low $\mathrm{MgO}$ content of the studied samples may derive extensive pyroxene ( \pm olivine) fractionation at depth (e.g., Troch et al. 2017). The presence of a plagioclase-clinopyroxene-rich deeper part within the magma storage system is supported by the younger SG04 sample, which contains abundant aggregates of plagioclase and clinopyroxene. The formation of the Šumovit Greben consists of two phases, starting with a lava dome/flow extrusion at ca. 2.9 Ma, which resulted in the formation of the main volume of the center. The observed differences in the three lower units, i.e. glassy foliated rhyolite, dark grey (partly devitrified) foliated rhyolite and light grey (devitrified) rhyolite represent the different lithofacies (from bottom to top: basal breccia, coherent glass, foliated rhyolite and microcrystalline rhyolite) of a slowly cooling rhyolitic lava dome/flow (e.g. Manley and Fink 1987). Remnants of a neck structure/feeder dyke mark the potential conduit(s) for the upwelling magmas (Fig. 4). A small-volume lava flow marks the end of the activity at ca. 2.8 Ma by the glassy SG04 rhyolite sample, which is present only on the northern part of the complex in a restricted area. Although the SG04 sample could be interpreted as the top glassy unit of a lava dome/flow, besides its slightly younger age $(2.78 \pm 0.08 \mathrm{Ma})$ compared to the other two samples $(2.89 \pm 0.08 \mathrm{Ma}$ and $2.87 \pm 0.08 \mathrm{Ma}$ ), it also exhibits mineralogical (presence of plagioclase-clinopyroxene aggregates) and geochemical differences (e.g., slightly lower $\mathrm{SiO}_{2}$ content, less depleted in Sr; Fig. 5). This differentiates it clearly from the underlying units, and supports an interpretation as a separate lava flow. The magma source for this last eruption could be a deeper part of the magma storage system based on the lack of quartz, the larger amount of plagioclase and clinopyroxene phenocrysts and glomeroporphyritic aggregates. The less evolved character of this last eruption is also supported by the higher $\mathrm{MgO}$ and $\mathrm{Sr}$ content. In addition, the slightly higher $\mathrm{Nd}$ and lower Sr isotopic composition (Figs. 5, 7) compared to the other samples of Šumovit Greben witness also a minor amount of digestion of crustal material during their differentiation path.

Although the obtained K-Ar age for Šumovit Greben (2.9-2.8 Ma) is close to one of the explosive units (ca. $2.6 \mathrm{Ma}$ ) identified by Vougioukalakis (2002), there is no clear connection between the pyroclastic and the rhyolitic complex neither on field nor in the available geochemical data. Therefore, further studies are needed to determine the possible relation of Šumovit Greben center with the neighboring pyroclastic deposits.

\section{Sr and $\mathrm{Nd}$ isotopic characteristics and their implication for magma source region}

The ${ }^{87} \mathrm{Sr} /{ }^{86} \mathrm{Sr}$ and ${ }^{143} \mathrm{Nd} /{ }^{144} \mathrm{Nd}$ isotope ratios of the studied sites fall into the enriched quadrant of the $\mathrm{Sr}-\mathrm{Nd}$ isotope diagram (Fig. 5) having higher $\left({ }^{87} \mathrm{Sr} /{ }^{86} \mathrm{Sr}>0.7045\right)$ and lower $\left({ }^{143} \mathrm{Nd} /{ }^{144} \mathrm{Nd}<0.512638\right)$ ratios than the bulk silicate earth ratios (Zindler and Hart, 1986), respectively. The ratios vary between $0.706749-0.709735$ for ${ }^{87} \mathrm{Sr} /{ }^{86} \mathrm{Sr}$ and $0.512257-0.512530$ for ${ }^{143} \mathrm{Nd} /{ }^{144} \mathrm{Nd}$ (Figs. 5, 7), which fall in the range of the previously studied samples.

The rhyolitic Šumovit Greben samples fall within the range of the previously studied sites of the Kožuf-Voras volcanic system. The isotopic signature of these samples can be explained by crustal contamination accompanying fractional crystallization during magma differentiation (Yanev et al. $2008 \mathrm{a}, \mathrm{b}$ ). The occurrence of significant crustal assimilation matching fractional crystallization can also explain the high variations of the $\mathrm{Ba} / \mathrm{Nb}$ ratios (19-223), the positive shift of ${ }^{87} \mathrm{Sr} /{ }^{86} \mathrm{Sr}(0.708000-0.709897)$ matched by a negative shift of ${ }^{143} \mathrm{Nd} /{ }^{144} \mathrm{Nd}$ isotopic composition $(0.512252-0.512382)$ for the Kožuf-Voras volcanic system (Fig. 5). The youngest 


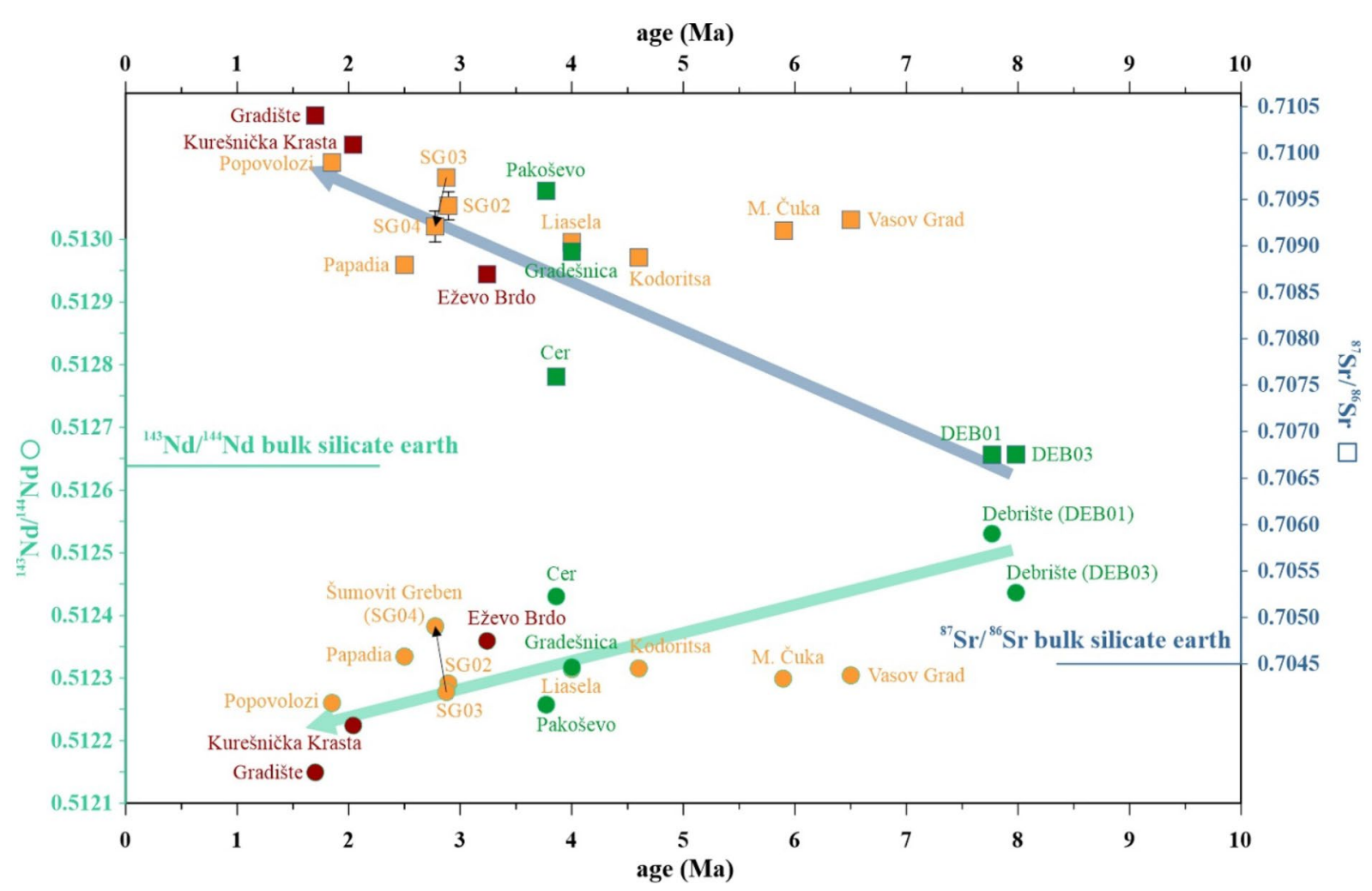

Fig. 7 The evoultion of the $\mathrm{Sr}$ (rectangles) and $\mathrm{Nd}$ (circles) isotopic ratio through time. Data from this study, Eleftheriadis et al. (2003), Cvetković et al. (2004), Yanev et al. (2008a) and Georgiev et al. (2014). The colored arrows highlight the overall increasing enrichment trend in the $\mathrm{Sr}$ and $\mathrm{Nd}$ isotopic ratio through time in case of the HMg-K and UK centers. Samples from the Kožuf-Voras volcanic

sample (SG04) has distinctly higher Nd and lower Sr isotopic value, indicating the extrusion of a less contaminated magma as the last phase of volcanism at Šumovit Greben, in line with our field and petrographic observations, i.e. its smaller extent and the presence of clinopyroxene-plagioclase aggregates in the sample.

Pakoševo exhibits higher ${ }^{87} \mathrm{Sr} /{ }^{86} \mathrm{Sr}$ and lower ${ }^{143} \mathrm{Nd} /{ }^{144} \mathrm{Nd}$ isotopic ratios compared to the other $\mathrm{HMg}-\mathrm{K}$ centers (Figs. 5, 7). This might be due to the presence of crustal xenoliths in the sample, reflecting a huge amount of digested crustal material, rather than the characters of its primary magmas and of the mantle source region. As this sample exhibits high $\mathrm{CaO}$ and $\mathrm{Sr}$ content together with high $\mathrm{Ba} / \mathrm{Nb}$, $\mathrm{Sr} / \mathrm{Y}$ and low $\mathrm{Sr} / \mathrm{Y}$ ratios, limestone digestion during magma uprise can also be considered as a main factor in its formation, testifying to the major role played by crustal assimilation during the magma ascent, even in less evolved samples.

Debrište, the oldest studied center $(8.0 \pm 0.2$ and $7.8 \pm 0.2 \mathrm{Ma})$ has the lowest ${ }^{87} \mathrm{Sr} /{ }^{86} \mathrm{Sr}$ and highest ${ }^{143} \mathrm{Nd} /{ }^{144} \mathrm{Nd}$ isotope ratios amongst all the centers in the region (Figs. 5, 7). As part of the HMg-K group of Yanev et al. (2008a, b), the studied samples (DEB01 and DEB03) system have a more or less uniform $\mathrm{Sr}$ and $\mathrm{Nd}$ isotopic variation. The smaller, black arrows for Šumovit Greben volcanic complex refer to a slightly less evolved magma from the deeper part of the magma storage. For the color coding please refer to Fig. 5. Bulk Earth $\mathrm{Sr}$ and $\mathrm{Nd}$ value $(0.7045$ and 0.512638 , respectively) are from Zindler and Hart (1986)

exhibit also the lowest $\mathrm{Ba} / \mathrm{Nb}$ ratios and these are the least enriched in HREE and LIL elements amongst the HMg-K centers (Fig. 5).

Compiling the present geochemical dataset with the previously reported one in case of the $\mathrm{HMg}-\mathrm{K}$ and the UK centers (Cvetković et al. 2004; Yanev et al. 2008a, b), while there are similarities in the major and trace element compositions in general, differences exist in their $\mathrm{Sr}$ and $\mathrm{Nd}$ isotopic ratios and in some of the trace element content (e.g. LILE; Fig. 5). Yanev et al. (2008a, b) concluded that the $\mathrm{HMg}-\mathrm{K}$ and the UK rocks were not affected by crustal contamination processes but their geochemical characteristics reflect a metasomatized lithospheric mantle, and the differences within the samples imply source heterogeneity. Debrište samples fit also into this interpretation, representing the lowest ${ }^{87} \mathrm{Sr} /{ }^{86} \mathrm{Sr}$ and highest ${ }^{143} \mathrm{Nd} /{ }^{144} \mathrm{Nd}$ isotope ratios, whereas the isotopic composition of Pakoševo might not reflect its original source region as discussed above. The increase in $\mathrm{Sr}$ isotopic ratios and the decrease in $\mathrm{Nd}$ isotopic ratios are coupled with an increase in the $\mathrm{Rb} / \mathrm{Nb}$ and $\mathrm{Ba} / \mathrm{Nb}$ ratios (Fig. 5) implying the addition of subduction-related material (melt or fluid from the subducted slab) to the mantle source (e.g. Agostini et al. 
2007). Although the occurrence of source contamination and crustal assimilation is somewhat difficult to differentiate, usually the variation of ${ }^{143} \mathrm{Nd} /{ }^{144} \mathrm{Nd}$ and ${ }^{87} \mathrm{Sr} /{ }^{86} \mathrm{Sr}$ isotope ratios at a given $\mathrm{SiO}_{2}$ is indicative of source contamination resulting in source heterogeneity. A positive ${ }^{87} \mathrm{Sr} /{ }^{86} \mathrm{Sr}$ vs. $\mathrm{SiO}_{2}$ correlation, as well as a negative ${ }^{143} \mathrm{Nd} /{ }^{144} \mathrm{Nd}$ vs. $\mathrm{SiO}_{2}$ correlation on the other hand, highlight the occurrence of crustal assimilation during magma evolution. The calculated crystallization pressures presented in Yanev et al. (2008a, b) and preliminary calculations for Pakoševo and Debrište samples based on clinopyroxene-liquid equilibria (Putirka et al. 1996; Putirka 2008; Supplementary Material) reflect lithospheric mantle depths (ca. 10-12 kbar, i.e., $~ 37-45 \mathrm{~km}$ ) for the source region of the magmas.

Although the isotopic variations could be solely explained by lithospheric mantle source heterogeneity, there is additionally a clear correlation in the $\mathrm{Sr}$ and $\mathrm{Nd}$ isotopic ratios with time in case of the HMg-K and UK centers (Fig. 7), even with Pakoševo sample excluded, as it might not simply reflect those of its source region. For these samples, some trace element contents and ratios (e.g., LILE, U, Th, Ba/ $\mathrm{Nb}$ ) also correlate with the decreasing eruption ages. Such element enrichments in general are considered as the result of the metasomatizing agent in the lithospheric mantle (e.g. Yanev et al. 2008a, b). The increase of the abovementioned trace elements, together with the increase in ${ }^{87} \mathrm{Sr} /{ }^{86} \mathrm{Sr}$ ratios and decrease in ${ }^{143} \mathrm{Nd} /{ }^{144} \mathrm{Nd}$ ratios possibly reflects an increasing rate of source contamination i.e., increasing rate of mantle metasomatism through time. The Debrište samples, which represent the oldest volcanic centers in the area show already the effect of a metasomatized lithospheric mantle having ratios enriched in radiogenic $\mathrm{Sr}$ and nonradiogenic $\mathrm{Nd}$ isotopes $(>0.705$ and $<0.512638$, respectively; Zindler and Hart 1986). Even though the small-scale lithospheric mantle heterogeneity cannot be excluded, the increasing trend in the trace element and $\mathrm{Sr}$, together with the decrease in $\mathrm{Nd}$ isotopic composition with time indicates that the lithospheric mantle region was possibly increasingly affected by the ongoing/continuing mantle metasomatism as a result of the southern/Aegean subduction front.

\section{Insight to the geodynamic evolution in the area}

The pathway for the erupted magmas could be the deepseated lithospheric faults along the main unit boundaries. Šumovit Greben center is situated at the junction of nappes composed of Cretaceous flysch and Jurassic serpentinites with a SW-NE fault which cuts through the area (Figs. 4, 6), whereas Debrište is located at a thrust fault along which Jurassic and Cretaceous units are overthrust onto Cretaceous units (Fig. 3b). The eruptions could have been triggered by the post-collisional extensional dynamics, causing decompression melting in the lithospheric mantle, possibly initiated by the accelerating clockwise rotation of the Hellenides during Middle to Late Miocene along the Scutari-Peć zone (Kissel et al. 1995). The Debrište volcanism, based on the newly obtained groundmass $\mathrm{K}-\mathrm{Ar}$ ages marks the reawakening of the Macedonian volcanism after almost $10 \mathrm{Ma}$ of quiescence. This event also marks the change from the orogenic magmatic cycle to the anorogenic magmatism in this region (Harangi et al. 2006; Lustrino and Wilson 2007). The time gap (ca. $10 \mathrm{Ma}$ ) revealed by this study between the two phases could also give an insight into how the transition occurs in similar extensional systems between the orogenic and anorogenic magmatism. The most intense phase of the first period of volcanism occurred during early Oligocene coinciding with the late Paleogene extensional period (Boev and Yanev 2001, Burchfiel et al. 2008). This was followed by a period of local shortening during late Oligocene-middle Miocene (Burchfiel et al. 2008). The renewal of volcanic activity was approximately coeval with the renewal of the extensional tectonic dynamics with a more mafic, metasomatized lithospheric mantle originated volcanic rocks with elevated $\mathrm{K}$ content in the central parts of the region. Towards the south, Kožuf-Voras volcanic system resembles similarities in the geochemical character to the Oligocene magmatic activity, with the subduction along the Aegean trench possibly playing a dominant role in its formation.

The position of Debrište center can also contribute to our understanding of the formation of the Tikveš basin. The onset of the basin opening occurred in Paleogene times, during the middle to late Eocene extension. A short compressional period in Late Oligocene-Early Miocene terminated this phase, but extensional dynamics started again to be dominant during the Late Miocene along NNW-trending faults which control the western edge of the basin (Dumurdzanov et al. 2005). The Debrište centers occur along the same NNW-trending fault line at the western edge of the basin and the volcanics here directly overlay the Jurassic-Cretaceous successions (Figs. 2, 3). This indicates that the volcanism marks the onset of the basin opening occurring at around $8 \mathrm{Ma}$. Interestingly, similar age was first reported for Kurešnička Krasta (9.5 Ma; Tersić and Svešnikova 1986; Fig. 2), located at the eastern edge of Tikveš basin, however, that was recently questioned, obtaining a much younger age for that locality $(2.1 \pm 0.1 \mathrm{Ma}$; Yanev et al. 2008a).

\section{Conclusion}

Three, previously unstudied volcanic sites were in the focus of this work, located at the westernmost edge of the Vardar zone, south from the Skutari-Peć fault zone, within the South Balkan extensional regime. Geochronology, general petrography, and whole-rock geochemical analyses, supplemented with $\mathrm{Sr}-\mathrm{Nd}$ isotopic composition were applied to 
unravel their volcanological evolution and relation to the contemporaneous volcanic centers in the region. Amongst the dated samples, all belonging to Late Miocene to Pleistocene volcanic phase, the oldest ones are located at Debrište (ca. 8-7.8 Ma), which marks the renewal of volcanism south from Skutari-Peć transverse zone after ca. $10 \mathrm{Ma}$ of quiescence and also the opening of Tikveš basin. The onset of volcanism can be related to the rotation of the Hellenides block along the Skutari-Peć transverse zone. Pakoševo center, the northernmost studied center formed at ca. 3.8 Ma at the southeast edge of the Skopje basin for which it provides the first radiometric constraint on the Solnje Formation. The rhyolitic Šumovit Greben, the southernmost studied center, developed at ca. 3.0-2.8 Ma at the edge of Mariovo basin as part of the large-volume Kožuf-Voras volcanic system formed from 6.5 to $1.8 \mathrm{Ma}$. The majority of the Kožuf-Voras volcanic massif developed between 6.5 and $4.0 \mathrm{Ma}$, whereas a younger phase (2.5-1.8 Ma) was known at the southwestern part of Kožuf-Voras. The formation of Šumovit Greben marks the possible onset of this younger activity starting at $3 \mathrm{Ma}$. The $\mathrm{Sr}$ and $\mathrm{Nd}$ isotopic ratios of the studied centers combined with available data from the other Late Miocene to Pleistocene volcanic localities indicate a possible increasing rate in lithospheric mantle source metasomatism with time beneath the Vardar zone.

Supplementary Information The online version contains supplementary material available at https://doi.org/10.1007/s00531-021-02153-2.

\begin{abstract}
Acknowledgements This research was supported by the European Union and the State of Hungary, financed by the European Regional and Development Fund in the project of GINOP-2.3.2-15-2016-00009 'ICER' project, and co-financed by the French-Hungarian Cooperation Program TÉT-FR-2018-00018. Fieldwork was carried out under Research Permit No. UP1-11/1-690/2019 issued by the Ministry of Environment and Physical Planning of the Republic of North Macedonia. The SEM measurements were financed by the GINOP-2.3.3-152016-00029 'HSLab' project. Financial support for sampling and K-Ar dating was also provided by the TelluS 2020 program of INSU, CNRS. This is Laboratoire de Géochronologie Multi-Techniques (LGMT) contribution number 168. K. Molnár benefitted of Trans National Access program of EU-HORIZON 2020 funded EPOS project N 676564 for Sr-Nd isotope analyses, which were also partially supported by IGGCNR Grant P0CT0061 by S. Agostini. The authors thank Wolf-Christian Dullo for the editorial handling of the manuscript and Georgia Pe-Piper, Albrecht von Quadt and an anonymous reviewer for their constructive comments and suggestions.
\end{abstract}

Funding Open access funding provided by ELKH Institute for Nuclear Research.

Open Access This article is licensed under a Creative Commons Attribution 4.0 International License, which permits use, sharing, adaptation, distribution and reproduction in any medium or format, as long as you give appropriate credit to the original author(s) and the source, provide a link to the Creative Commons licence, and indicate if changes were made. The images or other third party material in this article are included in the article's Creative Commons licence, unless indicated otherwise in a credit line to the material. If material is not included in the article's Creative Commons licence and your intended use is not permitted by statutory regulation or exceeds the permitted use, you will need to obtain permission directly from the copyright holder. To view a copy of this licence, visit http://creativecommons.org/licenses/by/4.0/.

\section{References}

Agostini S, Tokçaer M, Savaşçın MY (2010a) Volcanic rocks from Foça-Karaburun and Ayvalık-Lesvos Grabens (Western Anatolia) and their petrogenic-geodynamic significance. Turk J Earth Sci 19:157-184. https://doi.org/10.3906/yer-0905-11

Agostini S, Doglioni C, Innocenti F, Manetti P, Tonarini S (2010b) On the geodynamics of the Aegean rift. Tectonophysics 488:7-21. https://doi.org/10.1016/j.tecto.2009.07.025

Agostini S, Doglioni C, Innocenti F, Manetti P, Tonarini S, Savaşçın MY (2007). The transition from subduction-related to intraplate Neogene magmatism in the Western Anatolia and Aegean area. In: Beccaluva L, Bianchini G, Wilson M (eds) Cenozoic volcanism in the Mediterranean area: geological society of America special paper, vol 418, pp 1-15. https://doi.org/10.1130/2007.2418(01)

Arsovski M (1997) Tectonic of Macedonia. Rudarsko-Geol. Fac. Štip, p 306 (in Macedonian)

Bablon M, Quidelleur X, Samaniego P, Le Pennec J-L, Lahitte P, Liorzou C, Bustillos JE, Hidalgo S (2018) Eruptive chronology of Tungurahua volcano (Ecuador) revisited based on new K-Ar ages and geomorphological reconstructions. J Volcanol Geotherm Res 357:378-398. https://doi.org/10.1016/j.jvolgeores.2018.05.007

Bachmann O, Bergantz GW (2009) Rhyolites and their source mushes across tectonic settings. J Petrol 49:2277-2285. https://doi.org/ 10.1093/petrology/egn068

Boev B, Jankovic S, Serafimovski T (1997) Magmatism and Tertiary Mineralization of the Kožuf Metallogenetic District, the Republic of Macedonia with Particular Reference to the Alshar deposit. Special Publications, 5. Faculty of Mining and Geology. Stip, p 262

Boev B, Yanev Y (2001) Tertiary magmatism within the Republic of Macedonia: a review. Acta Vulcanol 13:57-72

Burchfiel BC, Nakov R, Dumurdzanov N, Papanikolaou D, Tzankov T, Serafimovski T, King RW, Kotzev V, Todosov A, Nurce B (2008) Evolution and dynamics of the Cenozoic tectonics of the South Balkan extensional system. Geosphere 4:919-938. https://doi.org/ 10.1130/GES00169.1

Carminati E, Doglioni C, Argnani A, Carrara G, Dabovski C, Dumurdzhanov N, Gaetani M, Georgiev G, Mauffret A, Nazai S, Sartori R, Scionti V, Scrocca D, Séranne M, Torelli L, Zagorchev I (2004) Transect III: Massif Central-Provence-Gulf of LionProvencal Basin-Sardinia-Tyrrhenian Basin-Southern Apennines-Apulia-Adriatic Sea-Albanides-Balkans-Moesian Platform. In: Cavazza W, Roure F, Spakman W, Stampfli GM, Ziegler $\mathrm{P}$ (eds) The TRANSMED Atlas, the Mediterranean Region from Crust to Mantle. Springer, Berlin

Cassignol C, Gillot P-Y (1982) Range and effectiveness of unspiked potassium-argon dating: experimental groundwork and applications. Wiley, Odin G.S

Cvetković V, Prelević D, Downes H, Jovanović M, Vaselli O, Pécskay $\mathrm{Z}$ (2004) Origin and geodynamic significance of Tertiary postcollisional basaltic magmatism in Serbia (central Balkan Peninsula). Lithos 73:161-186. https://doi.org/10.1016/j.lithos.2003.12.004

Dibacto S, Lahitte P, Karátson D, Hencz M, Szakács A, Biró T, Kovács I, Veres D (2020) Growth and erosion rates of the East Carpathians volcanoes constrained by numerical models: Tectonic and climatic implications. Geomorphology 368:107352. https://doi. org/10.1016/j.geomorph.2020.107352 
Druitt TH, Vougioukalakis GE (2019) South Aegean Volcanic Arc. Elements 15/3. ISSN 1811-5209

Dumurdzanov N, Serafimovski T, Burchfiel BC (2005) Cenozoic tectonics of Macedonia and its relation to the South Balkan extensional regime. Geosphere 1:1-22

Dumurdzanov N, Hristov S, Pavlovski B, Ivanova V (1981) Explanatory notes for sheets Vitolište and Kajmakčalan. General geological map $(1: 100,000)$ of the Socialist Federal Republic of Yugoslavia, Federal Geological Survey, Belgrade, p 61 (in Macedonian)

Dumurdzanov N, Serafimovski T, Burchfiel BC (2004) Evolution of the Neogene-Pleistocene Basins of Macedonia. Geological Society of America, Digital Map and Chart Series 1 (accompanying notes), $\mathrm{p} 20$

Eleftheriadis G, Castorina F, Soldatos T, Masi U (2003) Geochemical and $\mathrm{Sr}-\mathrm{Nd}$ isotopic evidence for the genesis of the Late Cainozoic Almopia volcanic rocks (Central Macedonia, Greece). Mineral Petrol 78:21-36. https://doi.org/10.1007/s00710-002-0217-0

Eleftheriadis G, Vougioukalakis G (2006) Geological overview of Almopia—volcanism. In: Tsoukala E (ed) A guide to Speleopark of Almopia. Geology-Paleontology-Speleology. Aridea, Greece, p 108

Fytikas M, Innocenti F, Manetti P, Mazzuoli R, Peccerillo A, Villari L (1984) Tertiary to Quaternary evolution of volcanism in the Aegean region. In: Dixon JE, Robertson AHF (eds) The geological evolution of the Eastern Mediterranean Geological Society of London, Special Publication, vol 17, pp 687-699

Georgiev S, Marchev P, Peitcheva I, von Quadt A, Vaselli O (2013) Miocene extensional magmatic activity along Strymon valley and Doyran region, Bulgaria, Greece and the Former Yugoslav Republic of Macedonia. Acta Vulcanol 25(1-2):153-168

Georgiev S, Peytcheva I, von Quadt A (2014) Petrology and zircon $\mathrm{U}-\mathrm{Pb}$ geochronology of trachytes from Kozhuf paleovolcano, FYROM-adakite-like signatures by amphibole fractionation. Proceedings of XX CBGA Congress, Tirana, Albania. Bul Shk Gjeol 1:437-440

Gillot PY, Cornette Y (1986) The Cassignol technique for potassiumArgon dating, precision and accuracy: examples from the Late Pleistocene to recent volcanics from southern Italy. Chem Geol Isotope Geosci Sect 59:205-222. https://doi.org/10.1016/01689622(86)90072-2

Gillot P-Y, Cornette Y, Max N, Floris B (1992) Two reference materials, trachytes Mdo-G and Ish-G, for Argon Dating (K-Ar and ${ }^{40} \mathrm{Ar} /{ }^{39} \mathrm{Ar}$ ) of Pleistocene and Holocene rocks. Geostand Newsl 16:55-60. https://doi.org/10.1111/j.1751-908X.1992.tb00487.x

Gillot P-Y, Hildenbrand A, Lefevre JC, Albore-Livadie C (2006) The $\mathrm{K} /$ Ar dating method: principle, analytical techniques, and application to Holocene volcanic eruptions in southern Italy. Acta Vulcanol 18:55-66

Handy MR, Giese J, Schmid SM, Pleuger J, Spakman W, Onuzi K, Ustaszewski K (2019) Coupled crust-mantle response to slab tearing, bending, and rollback along the Dinaride-Hellenide Orogen. Tectonics 38:2803-2828. https://doi.org/10.1029/2019TC005524

Harangi S, Downes H, Seghedi I (2006) Tertiary-Quaternary subduction processes and related magmatism in the Alpine-Mediterranean region. In: Gee D, Stephenson R (eds) European lithosphere dynamics. Geological Society of London, Memoirs, vol 32, pp 167-190. https://doi.org/10.1144/GSL.MEM.2006.032.01.10

Harangi S, Lenkey L (2007) Genesis of the Neogene to Quaternary volcanism in the Carpathian-Pannonian region: role of subduction, extension and mantle plume. Geol Soc Am Spec Pap 418:67-92. https://doi.org/10.1130/2007.2418(04)

Innocenti F, Agostini S, Doglioni C, Manetti P, Tonarini S (2010) Geodynamic evolution of the Aegean: constraints from the PlioPleistocene volcanism of the Volos-Evia area. J Geol Soc Lond 167:1-15. https://doi.org/10.1144/0016-76492009-149
Karajovanovik M, Hadži-Mitrova S (1982) Explanatory notes for sheet Veles. General geological map (1:100 000) of the Socialist Federal Republic of Yugoslavia, Federal Geological Survey, Belgrade, $p$ 66 (in Macedonian)

Karamata S, Stojanov R, Serafimovski T, Boev B, Aleksandrov M (1992) Tertiary magmatism in the Dinarides and the Serbo-Macedonian massif. Geol Maced 6(2):127-186

Kissel C, Speranza F, Milicevic V (1995) Paleomagnetism of external southern and central Dinarides and northern Albanides: implications for the Cenozoic activity of the Scutari-Pec Transverse Zone. J Geophys Res Solid Earth 100:14999-15007. https://doi.org/10. 1029/95JB01243

Kolios N, Innocenti F, Manetti P, Peccerillo A, Giuliani O (1980) The Pliocene volcanism of the Voras Mts (Central Macedonia, Greece). Bull Volcanol 43:553-568. https://doi.org/10.1007/ BF02597692

Kossmat F (1924) Geologie der zentralen Balkanhalbinsel. In: Mit Einer Übersicht Des Dinarischen Gebirgbaus. Verlag Gebrüder Bornträger, Berlin

Lahitte P, Dibacto S, Karátson D, Gertisser R, Veres D (2019) Eruptive history of the Late Quaternary Ciomadul (Csomád) volcano, East Carpathians, part I: timing of lava dome activity. Bull Volcanol 81:27. https://doi.org/10.1007/s00445-019-1286-9

Le Bas MJ, Le Maitre RW, Woolley AR (1992) The construction of the total alkali-silica chemical classification of volcanic rocks. Mineral Petrol 46:1-22. https://doi.org/10.1007/BF01160698

Lippolt HJ, Fuhrmann U (1986) K-Ar age determination on volcanics of Alsar mine/Yugoslavia. In: Nolte E (ed) Proceed. workshop on the feasibility of solar neutrino detection with ${ }^{206} \mathrm{~Pb}$ by geochemical and mass spectroscopical measurements. Report GSI-86-9, Technische Universität, München

Lustrino M, Wilson M (2007) The circum-Mediterranean anorogenic Cenozoic igneous province. Earth Sci Rev 81:1-65. https://doi. org/10.1016/j.earscirev.2006.09.002

Lustrino M, Ronca S, Caracausi A, Ventura Bordenca C, Agostini S, Faraone BD (2020) Strongly $\mathrm{SiO}_{2}$-undersaturated, CaO-rich kamafugitic Pleistocene magmatism in Central Italy (San Venanzo volcanic complex) and the role of shallow depth limestone assimilation. Earth Sci Rev 208:103256. https://doi.org/10.1016/j.earsc irev.2020.103256

Manley CR, Fink JH (1987) Internal textures of rhyolite flows as revealed by research drilling. Geology 1987(15):549-552. https:// doi.org/10.1130/0091-7613(1987)15\%3c549:ITORFA\%3e2.0. $\mathrm{CO} ; 2$

Mitrev S, Popov M (2021) Petrological and geochemical characteristics of the tertiary volcanic rocks from the locality Golema Čuka, Bogdanci District, Republic of North Macedonia. In: Proceedings of 4 Macedonian geological congress. Geologica Macedonica No. $5: 34-42$

Nakamura N (1974) Determination of REE, Ba, Fe, Mg, Na and K in carbonaceous and ordinary chondrites. Geochim Cosmochim Acta 38(5):757-775. https://doi.org/10.1016/0016-7037(74)90149-5

Neubauer F, Pavićević MK, Genser J, Jelenković R, Boev B, Amthauer $\mathrm{G}(2009){ }^{40} \mathrm{Ar} /{ }^{39} \mathrm{Ar}$ dating of geological events of the Allchar deposit and its host rocks. In: Goldschmidt Conference, A938

Peccerillo A, Taylor SR (1976) Geochemistry of eocene calc-alkaline volcanic rocks from the Kastamonu area, Northern Turkey. Contrib Miner Petrol 58:63-81. https://doi.org/10.1007/BF00384745

Pe-Piper G, Piper DJW (2002) The igneous rocks of Greece. The anatomy of an orogen. Beiträge zur regionalen Geologie der Erde (Series). Gebrüder Borntraeger, Stuttgart, pp xvi+573. (ISBN 978-3-443-11030-7)

Pe-Piper G, Piper DJW (2007) Neogene backarc volcanism of the Aegean: new insights into the relationship between magmatism 
and tectonics. Geol Soc Am Spec Pap 418:17-31. https://doi.org/ $10.1130 / 2007.2418(02)$

Putirka K (2008) Thermometers and barometers for volcanic systems. Rev Mineral Geochem 69:61-120. https://doi.org/10.2138/rmg. 2008.69.3

Putirka K, Johnson M, Kinzler R, Longhi J, Walker D (1996) Thermobarometry of mafic igneous rocks based on clinopyroxene-liquid equilibria, 030 kbar. Contrib Miner Petrol 123:92. https://doi.org/ 10.1007/s004100050145

Quidelleur X, Gillot P-Y, Soler V, Lefèvre J-C (2001) K/Ar dating extended into the last millennium: application to the youngest effusive episode of the Teide Volcano (Spain). Geophys Res Lett 28:3067-3070. https://doi.org/10.1029/2000GL012821

Raczek I, Stoll B, Hofmann AW, Peter Jochum K (2001) High-precision trace element data for the USGS reference materials BCR1, BCR-2, BHVO-1, BHVO-2, AGV-1, AGV-2, DTS-1, DTS-2, GSP-1 and GSP 2 by ID-TIMS and MIC-SSMS. Geostand Newslett 25:77-86. https://doi.org/10.1111/j.1751-908X.2001.tb007 89. $\mathrm{x}$

Rakićević T, Stojanov R, Arsovski M (1973) Explanatory notes for sheet Prilep. General geological map $(1: 100,000)$ of the Socialist Federal Republic of Yugoslavia, Federal Geological Survey, Belgrade, $\mathrm{p} 65$ (in Macedonian)

Samper A, Quidelleur X, Komorowski J-C, Lahitte P, Boudon G (2007) Effusive history of the Grande Découverte Volcanic Complex, southern Basse-Terre (Guadeloupe, French West Indies) from new K-Ar Cassignol-Gillot ages. J Volcanol Geotherm Res 187:117130. https://doi.org/10.1016/j.jvolgeores.2009.08.016

Schmid SM, Fügenschuh B, Kounov A, Mațenco L, Nievergelt P, Oberhänsli R, Pleuger J, Schefer S, Schuster R, Tomljenović B, Ustaszewski K, van Hinsbergen DJJ (2020) Tectonic units of the Alpine collision zone between Eastern Alps and western Turkey. Gondwana Res 78:308-374. https://doi.org/10.1016/j.gr.2019.07. 005

Serafimovski T, Boev B (1996) Metallogeny of the Kratovo-Zletovo volcano-intrusive complex. Terranes Serbia 356:347-352

Serafimovski T, Tasev G, Palinkaš SS, Palinkaš LA, Gjorgjiev L (2016) Porphyry $\mathrm{Cu}$ mineralization related to the small Tertiary volcanic intrusion in the Bučim ore deposit, Eastern Macedonia. Geol Croat 69(1):101-119. https://doi.org/10.4154/GC.2016.09
Steiger RH, Jäger E (1977) Subcommission on geochronology: convention on the use of decay constants in geo- and cosmochronology. Earth Planet Sci Lett 36:359-362. https://doi.org/10.1016/0012821X(77)90060-7

Stojanov R, Sveshnikova E (1985) Alcali-trachite and skarns bisides Mrdaja near Lake Dojran. Geol Maced 1:181-190

Sun SS, McDonough WF (1989) Chemical and isotopic systematics of oceanic basalts: implications for mantle composition and processes. Geol Soc Lond Spec Publ 42(1):313-345. https://doi.org/ 10.1144/GSL.SP.1989.042.01.19

Tersić M, Svešnikova EV (1986) Age of the leucite rocks in Yugoslavia. Sbornik Serb Acad Nauki Belgrade 3:283-288

Troch J, Ellis BS, Mark DF, Bindeman IN, Kent AJR, Guillong M, Bachmann O (2017) Rhyolite generation prior to a yellowstone supereruption: insights from the Island Park-Mount Jackson Rhyolite series. J Petrol 58:29-52. https://doi.org/10.1093/petrology/ egw071

van Hinsbergen DJJ, Langereis CG, Meulenkamp JE (2005) Revision of timing, magnitude and distribution of Neogene rotations in the western Aegean region. Tectonophysics 396:1-34. https://doi.org/ 10.1016/j.tecto.2004.10.001

Vougioukalakis G (1994) The Pliocene volcanites of the Voras mountain, Central Macedonia, Greece. Bull Geol Soc Greece XXX/1:223-240 (in Greek)

Vougioukalakis G (2002) Petrological, geochemical and volcanological study of the Almopias Pliocene volcanic formations and their correlation with the geothermal manifestations in the area. $\mathrm{PhD}$ Thesis. Aristotle University of Thessaloniki, p 303 (in Greek)

Yanev Y, Boev B, Doglioni C, Innocenti F, Manetti P, Pécskay Z, Tonarini S, D'Orazio M (2008a) Late miocene to pleistocene potassic volcanism in the Republic of Macedonia. Mineral Petrol 94:4560. https://doi.org/10.1007/s00710-008-0009-2

Yanev Y, Boev B, Manetti P, Ivanova R, D’Orazio M, Innocenti F (2008b) Mineralogy of the Plio-Pleistocene potassic and ultrapotassic volcanic rocks from the Republic of Macedonia. Geochem Mineral Petrol Sofia 46:35-67

Zindler A, Hart SR (1986) Chemical geodynamics. Annu Rev Earth Planet Sci 14:493-570. https://doi.org/10.1146/annurev.ea.14. 050186.002425 